University of Chicago Law School

Chicago Unbound

\title{
The Credibility Imperative: The Political Dynamics of Retaliation in the World Trade Organization's Dispute Resolution Mechanism
}

Jide Nzelibe

Follow this and additional works at: https://chicagounbound.uchicago.edu/public_law_and_legal_theory

Part of the Law Commons

Chicago Unbound includes both works in progress and final versions of articles. Please be aware that a more recent version of this article may be available on Chicago Unbound, SSRN or elsewhere.

\section{Recommended Citation}

Jide Nzelibe, "The Credibility Imperative: The Political Dynamics of Retaliation in the World Trade Organization's Dispute Resolution Mechanism" (University of Chicago Public Law \& Legal Theory Working Paper No. 55, 2004).

This Working Paper is brought to you for free and open access by the Working Papers at Chicago Unbound. It has been accepted for inclusion in Public Law and Legal Theory Working Papers by an authorized administrator of Chicago Unbound. For more information, please contact unbound@law.uchicago.edu. 


\section{CHICAGO}

Public LaW and Legal Theory Working Paper No. 55

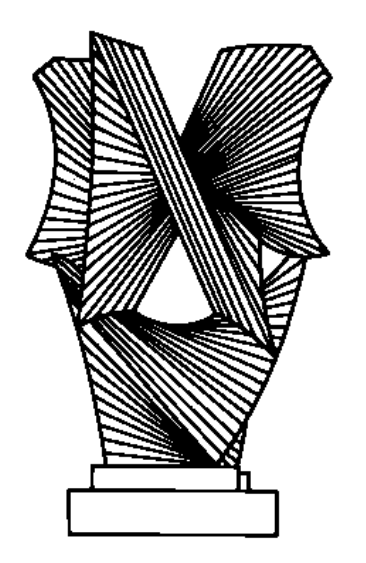

\section{THE CREDIBILITY IMPERATIVE: \\ The Political DYNAMics Of RETALiATION IN THE WORLD TRADE ORGANIZATION'S DISPUTE RESOLUTION MECHANISM}

Jide Nzelibe

THE LAW SCHOOL

THE UNIVERSITY OF CHICAGO

January 2004

This paper can be downloaded without charge at

http://www.law.uchicago.edu/academics/publiclaw/index.html

and at The Social Science Research Network Electronic Paper Collection:

http://ssrn.com/abstract_id=495571 


\title{
The Credibility Imperative: The Political Dynamics of Retaliation in the World Trade Organization's Dispute Resolution Mechanism
}

\author{
Jide Nzelibe*
}

Under the WTO's dispute settlement procedures, a party that has been injured by a scofflaw state's failure to comply with its trade obligations may retaliate against the scofflaw state by withdrawing equivalent trade concessions. Legal and economic commentators generally view retaliation as an economically perverse strategy for enforcing free trade norms. This Article explores an alternative explanation, arguing that retaliation may provide the optimal enforcement mechanism for trade liberalization given the prevalence of low compliance incentives and high enforcement costs in international cooperation agreements. This Article argues that retaliation is superior to other remedial options because it enables an injured state to inflict maximum political costs on the scofflaw state by mobilizing powerful export groups in the scofflaw state against protectionist policies. Furthermore, this Article shows how the presence of significant protectionist groups in the injured state, which stand to benefit from retaliatory measures, also improves the injured state's ability to commit to retaliation. Even if states have asymmetric preferences about protectionist policies, however, retaliation threats can still be credible since there is uncertainty about each state's retaliation costs. Finally, this Article concludes that contrary to the conventional wisdom, the substantial role of uncertainty in this model suggests that specific performance, and not compensation, ought to be the goal of the WTO's enforcement mechanism.

\section{INTRODUCTION}

One of the most significant innovations of the 1994 Uruguay round of trade talks was the formalization of a dispute resolution or enforcement mechanism under the auspices of the World Trade Organization ("WTO"). ${ }^{1}$ At the heart of this enforcement mechanism is the principle of retaliation or negative reciprocity. Specifically, the WTO authorizes states that are harmed by uncured rule violations to retaliate by suspending

* Bigelow Fellow and Lecturer in Law, University of Chicago Law School. Thanks to Bruce Johnsen, Alan Sykes, Adam Cox, James Spindler, Elizbeth Emens, Richard Epstein, Robert Howse and participants in a conference sponsored by the Cegla Center at Tel Aviv University on "The Role and Limits of Legal Regulation of Conflicts of Interest" held at the University of Pennsylvania Law School.

${ }^{1}$ See Agreement Establishing the World Trade Organization, Apr. 15 1994, in World Trade Organization, The Legal Texts: The Results of the Uruguay Round of Multilateral Trade 
equivalent "concessions or other obligations under the covered agreements." ${ }^{2}$ In other words, the enforcement strategy under the WTO is a tit-for-tat approach; if state A is found to breach its obligations to state $\mathrm{B}$, and state A refuses to remedy the breach, state $\mathrm{B}$ can suspend an equivalent measure of its market access obligations to state $\mathrm{A}$.

Economists and legal scholars typically view retaliation as an economically perverse strategy for enforcing free trade norms. ${ }^{3}$ Indeed, retaliation seems to flout the most basic conflict of interest principles by making protectionist groups-the very enemies of free trade at home-the beneficiaries of the WTO's remedial scheme. Understandably, these critics recommend that the current retaliation system be replaced by more trade friendly alternatives, such as mandatory monetary compensation or collectively-imposed sanctions.

This Article explores an alternative explanation of the retaliation mechanism, arguing that it provides the optimal enforcement strategy for trade liberalization given the prevalence of two major obstacles to international cooperation: low compliance incentives and high enforcement costs. By providing incentives for domestic interest groups to monitor violations and to follow through on enforcement threats, the retaliation mechanism perpetuates credibility in the WTO's dispute resolution mechanism. Two major interest group dynamics characterize this enforcement strategy.

First, retaliation increases compliance by mobilizing powerful interest groups in the scofflaw state—export interests—-to fight against pro-protectionist policies. While other commentators have also observed this specific attribute of retaliation, ${ }^{4}$ they have not sufficiently analyzed its public choice features in the context of alternative remedial schemes. As a compliance strategy, targeting export groups for retaliation is optimal because it is self-enforcing and it exacts the maximum political costs on politicians in the

\footnotetext{
Negotiations (1999) (hereinafter WTO Agreement). Annex 1A of the WTO Agreement largely incorporates the General Agreement of Trade and Tariffs of 1947. See General Agreement of Tariffs and Trade, October 30, 1947, T.I.A.S. No. 1700, 55 UNTS 194 (hereinafter GATT).

${ }^{2}$ Understanding on Rules and Procedures Governing the Settlement of Disputes, Art.22.2, WTO Agreement (hereinafter DSU).

${ }^{3}$ For the critical commentary on the retaliation mechanism, see infra text accompanying notes 40-48.

${ }^{4}$ See infra text accompanying note 22.
} 
scofflaw state. In contrast, an alternative remedy like monetary compensation would not only lack a self-enforcing mechanism, it would also tend to deflect the costs of noncompliance among a weak, widely dispersed, interest group. Other remedial alternatives, such as collective enforcement or suspension, are also inadequate either because they oversupply protectionist benefits or are simply not credible.

Second, since retaliation provides a substantial benefit to protectionist groups in the injured country, it increases the credibility of enforcement threats. Ordinarily, threats by an injured country to retaliate against a scofflaw state by raising tariffs may lack credibility because retaliation imposes a welfare loss on the injured state. An injured state may nonetheless be willing to retaliate if retaliation enables it to meet the demands of a domestic protectionist audience. Thus, the presence of a politically significant protectionist group improves the injured state's ability to commit to retaliation by making retaliation less political costly. Paradoxically, this interest group dynamic suggests a somewhat counterintuitive result: in a world where certain states have incentives to defect from their trade obligations, a state that faces significant domestic protectionist pressures might better serve the liberalization goals of the WTO because such a state can better signal its resolve to commit to a course of retaliation.

An important feature of the foregoing framework is the role of uncertainty or asymmetric information, in which each state is uncertain about the other's true political costs of retaliation. Were complete information available, a state with a strong protectionist domestic audience would have an incentive to breach its commitments to a state with a weak domestic protectionist audience. This is because a state that is less able to generate domestic political support for protectionist policies is less likely to commit itself to a long course of retaliation. Assuming a rational choice model, however, threats to retaliate may still be credible because it is very difficult for a state to observe the true political costs of retaliation to another state and certain states may have an incentive to misrepresent such costs. Thus, even if a particular state lacks a significant protectionist domestic audience, it may have a strong incentive to mimic the behavior of a state that does in order to deter prospective scofflaw states from breaching their international trade obligations. 
The importance of uncertainty in this model suggests that, contrary to the conventional wisdom, the goals of the WTO's enforcement mechanism ought to be specific performance rather than compensation. ${ }^{5}$ Optimal deterrence occurs not necessarily when retaliation actually takes place, but when there is a threat to retaliate and there is considerable uncertainty about the political costs or benefits of retaliation to the injured state. Sustained non-compliance undermines this uncertainty feature, however, by enabling the scofflaw state to discern the injured state's true preferences regarding retaliation. For instance, a scofflaw state would be able to discern that an injured state has high retaliation costs if the injured state is put to the test and is unable to retaliate for a sustained period of time. Because of this involuntary information disclosure, such an injured state may no longer have threats that are credible to deter the scofflaw state (or any other state) from future violations. This information-forcing role that is inherent in a compensation model of enforcement is potentially destabilizing to the free trade regime.

This Article proceeds as follows. Part I provides some relevant background on the relationship between free trade agreements and domestic interest groups. Part II examines the tactical role that retaliation plays in using export groups to force politicians in the scofflaw state to internalize the costs of protectionist measures. This Part explores briefly other alternatives to retaliation, such as monetary compensation and group sanctions, and concludes that retaliation is superior to these alternatives as an enforcement strategy. Part III explores how, in the presence of uncertainty regarding a state's domestic preferences, protectionist groups may influence a state's ability to make credible enforcement threats. Part IV explores the role of uncertainty in the ongoing debate regarding the remedial goals of the WTO enforcement regime and concludes that specific performance is preferable to a compensation approach.

\section{TRADE AgreEMENTS, ReCiprocity, AND INTEREST GROUPS}

For many years, economists and political scientists have attempted to explain international cooperation as the result of the interaction of rational egoists acting to

\footnotetext{
${ }^{5}$ See infra text accompanying notes 53-61.
} 
maximize aggregate welfare or some other conception of the national interest. ${ }^{6}$ In these state-centered models, the role of domestic actors in formulating international trade policy was largely ignored. Recently, however, influenced by the insights of public choice theory, more commentators are beginning to explain international trade agreements in terms of the competition for influence by domestic interest groups. ${ }^{7}$ In this model, commentators do not pay much attention to states and political actors because they are regarded merely as tools for transmitting the preferences of dominant domestic interest groups.

According to the interest group approach, states enter into international trade agreements not necessarily because they seek to maximize aggregate welfare but because they are responding to pressure from special industry interests. ${ }^{8}$ Indeed, interest group theory predicts that politicians have very little incentive to focus on the interests of consumer groups that benefit from trade liberalization since such groups tend to lack political influence due to collective action problems. Rather, free trade agreements can be explained as the result of the emerging political influence of export-oriented groups seeking increased access to foreign markets. As more free trade agreements are signed, and the gains from liberalization are consolidated, the political power of these exportoriented groups grows relative to that of protectionist groups. ${ }^{9}$ But since domestic protectionist groups still command significant political influence, very few free trade agreements completely liberalize trade. Rather, most free trade agreements provide for

\footnotetext{
${ }^{6}$ See, e.g., John Kennan and Raymond Reizman, Do Big Countries Win Tariff Wars, 29 INT'L ECON. REV. 81 (1988); David A. Lake, Beneath the Commerce of Nations: A Theory of International Economic Structures, 28 INT'L STUD. Q. 143 (1984); Stephen Krasner, State Power and the Structure of International Trade, 28 WORLd POL. 317 (1976); Harry G. Johnson, Optimum Tariffs and Retaliation, 21 REV. ECON. STUD. 21 (1954). For a detailed critique of the state-centered or structural approach see Timothy J. McKeown, The Limitations of "Structural" Theories of Commercial Policy, 40 INT'L ORG. 43 (1986).

${ }^{7}$ See e.g., Alan Sykes \& Warren Schwartz, The Economic Structure of Renegotiation and Dispute Resolution in the World Trade Organization, 31 J. LEGAL STUD. 179, 194-95 (2002); ROBERT BALDWIN, THE POLITICAL ECONOMY OF U.S. IMPORT POlicy (1996); Gene Grossman \& Elhanan Helpman, Protection for Sale, 84 AMER. ECO. REV. 84, 84-86 (1994). For a more in depth comparison of the state-centered and interest group approaches see John Ikenberry, David Lake \& Michael Mastunduno, Introduction: Approaches to Explaining American Foreign Economic Policy, 42 INT'L ORG. 1 (1988).

${ }^{8}$ See Gene Grossman \& Elhanan Helpman, Trade Wars and Trade Talks, 103 J POL. ECON. 675, 676 (1995).

${ }^{9}$ See Sykes \& Schwartz, The Economic Structure, supra note 7 at 194-95.
} 
some level of tariff protection and also provide for some safeguards, such as Article IX of the GATT, which enable states to grant temporary protection to ailing import-competing industries. ${ }^{10}$

Both the empirical evidence and the institutional framework of international trade regimes support the interest group explanation of international trade agreements. ${ }^{11}$ For instance, the role of reciprocity in the international bargaining process suggests that most states treat access to their markets as precious assets that they are only willing to give up in exchange for equivalent access to foreign markets. This approach makes sense if we assume that politicians are willing to sacrifice political support from protectionist groups in return only for more substantive support from export interest groups. It does not make much sense, however, if one adopts the state-centered assumption that states only seek to maximize aggregate welfare. As economists concede, states simply seeking to maximize aggregate welfare would chose free trade as the dominant strategy regardless of the strategy of other states. ${ }^{12}$ But why then would states seek concessions in order to do what is ostensibly in their interests? As Paul Krugman has observed, the reciprocity approach to trade bargaining cannot be understood purely in economic terms:

Anyone who has tried to make sense of international trade negotiations eventually realizes that they can only be understood by realizing that they are a game scored according to mercantilist rules, in which an increase in exports . .. is a victory, and an increase in imports ... is a defeat. The implicit mercantilist theory does not make sense ... but it nonetheless governs actual policy. ${ }^{13}$

\footnotetext{
${ }^{10}$ See Alan Sykes, Protectionism as a "Safeguard": A Positive Analysis of the GATT "Escape Clause" with Normative Speculations, 58 U. CHI. L. REV. 255, 259 (1991).

${ }^{11}$ See Robert E. Baldwin, The Political Economy of Trade Policy: Integrating the Perspectives of Economists and Political Scientists, in The Political Economy Of Trade Policy (Feenstra et. al ed., 1996) (listing empirical studies providing support for interest group explanation of international trade policy).

${ }^{12}$ Paul Krugman, What Should Trade Negotiators Negotiate About?, 35 J ECON. LIT. 113, 113 (1997).

${ }^{13} \mathrm{Id}$. at 114 .
} 
The principle of reciprocity inherent in international trade negotiations also features elsewhere in the WTO/GATT legal system. For instance, under the renegotiation provision of Article XXVIII of the GATT, a state may propose to modify or withdraw a tariff to which it has previously agreed in a prior negotiation. ${ }^{14}$ If the state fails to reach an agreement with any state that would be affected by the proposed new tariff, however, it is free to make the change, but the affected states are allowed to withdraw substantially equivalent concessions. ${ }^{15}$

Finally, reciprocity also plays a role in the WTO's enforcement mechanism. Under the WTO's Dispute Settlement Understanding (DSU), if a panel or appellate body concludes that a member has breached its obligations under a covered agreement, it will recommend that such a member "bring the measure into conformity with the agreement. ${ }^{16}$ If the non-compliant member fails to conform within a reasonable period of time, then the DSU requires that such a member enter into negotiations over compensation with the injured member. ${ }^{17}$ The DSU makes it clear, however, that compensation is only be a temporary measure, and that compliance with the panel's recommendations is the desired outcome. ${ }^{18}$ If negotiations over compensation fail, the injured member may request authority to suspend trade concessions "equivalent to the level of nullification and impairment." ${ }^{19}$ Once again, however, the DSU clarifies that this

${ }^{14}$ See GATT, supra note 1, art. XXVIII(2) ("In such negotiations and agreement . . . the contracting parties concerned shall endeavour to maintain a general level of reciprocal and mutually advantageous concessions not less favourable to trade than that provided for in this Agreement prior to such negotiations.").

${ }^{15}$ Id. at art XXVIII(3)(a) ("[T]he contracting party which proposes to modify or withdraw the concession shall, nevertheless, be free to do so and if such action is taken any contracting party with which such concession as initially negotiated ... shall then be free ... to withdraw . . . substantially equivalent concessions negotiated with the applicant contracting party.").

${ }^{16}$ DSU, supra note 2, art. 19.1.

${ }^{17} \mathrm{Id}$. art. 22.2.

${ }^{18}$ Id. art. 22.1 ("Compensation and the suspension of concessions or other obligations are temporary measures available in the event that recommendations and rulings are not implemented within a reasonable period of time. However, neither compensation nor the suspension of concessions is preferred to full implementation of a recommendation to bring a measure into conformity with the covered agreements.").

${ }^{19} \mathrm{Id}$. art. 22.4 
retaliation remedy is temporary and should last only until the scofflaw member complies with the panel's recommendations. ${ }^{20}$

\section{EXPORT INTEREST GROUP LINKAGE IN ENFORCING INTERNATIONAL TRADE AgreEMENTS}

The consequences of how the interaction of domestic interest groups affects the negotiation of international trade agreements has been elaborated on in a number of studies over the past couple of decades. ${ }^{21}$ But studies of how such interest groups affect the enforcement mechanism have been less developed. For instance, although there have been public choice studies on how retaliation encourages export groups to favor liberalization policies, ${ }^{22}$ such studies overlook any comparison of the efficacy of retaliation to alternative enforcement mechanisms. The following two sections argue that retaliation is superior to the myriad other remedial alternatives because it best forces the scofflaw state to internalize the political costs of non-compliance.

\section{A. Retaliation as a Strategy for Mobilizing Export Groups against Protectionist Policies}

The key role that protectionist interest groups play in fomenting the violation of international trade agreements is well documented. Once one recognizes that domestic pressures provide politicians with incentives to renege on their prior international trade commitments, it becomes necessary to establish enforcement regimes of varying intricacy to handle these problems. Interestingly, one would expect that the best remedial strategy, from an economic point of view, would punish the protectionists responsible for the

\footnotetext{
${ }^{20} \mathrm{Id}$. art. 22.1.

${ }^{21}$ See, e.g., Grossman and Helpman, supra note 7 at 111; Gene Grossman \& Elhanan Helpman, The Politics of Free Trade Agreements, 105 Am. ECON. REV. 667 (1995); Robert Baldwin \& Richard Clarke, Game-modeling Multilateral Trade Negotiations, 9 J POL. MOD. 257 (1987).

${ }^{22}$ See, e.g., Judith Goldstein, International Institutions and Domestic Politics: GATT, WTO, and the Liberalization of Trade, in THE WTO AS AN INTERNATIONAL ORGANIZATION 133, 144-46 (Anne O. Krueger, ed. 1998); see also Mark Movsesian, Enforcement of WTO Rulings: An Interest Group Analysis, 32 HOFSTRA L. REV. (forthcoming 2003).
} 
breach and compensate the export interest groups that have been injured by the loss of trade concessions. But such a strategy overlooks a fairly insuperable obstacle: the sovereignty of the state parties to the agreement. In other words, the existence of intervening independent political institutions makes it fairly difficult for export interest groups from one state to influence directly the incentives of protectionist groups in another state.

In view of the significant political access costs associated with the first-best solution, a second-best approach that takes account of the actual interest group dynamics that exist across sovereign borders is preferable. One such approach involves the strategic use of tariff schedules by the home state to mobilize export interest groups in a foreign state against protectionist groups within the same state. This is precisely the strategy embraced by the WTO's enforcement mechanism. In other words, retaliation has the property of making political decisions that benefit protectionist interest groups directly adverse to the interests of domestic export interest groups.

The political economy of retaliation involves the strategic interaction between domestic export interest groups and their foreign counterparts. This strategic interaction can be decomposed into two stages:

1. The information production stage: this is when export interest groups in an injured state inform their politicians about a possible breach and attempt to lobby for a response.

2. The response stage: This is when the export interest groups in the injured state lobby for targeted retaliation to inflict the most damage on strategic export interests in the scofflaw state.

At the information production stage, the export interest groups perform an educational function by making politicians in the injured state aware of the possible breach of a trade obligation by the scofflaw state. To the extent the injury caused by the treaty-inconsistent behavior of a foreign state is concentrated on few export interests, they are likely to overcome collective action problems and lobby for a political response. 
Politicians in the injured state who fail to respond to the scofflaw state's breach of its trade commitments can expect to pay a heavy price in terms of lost political patronage by these export groups. Because consumers typically suffer from collective action problems, however, it is safe to assume that the politicians may be willing to impose welfare losses on consumers to satisfy the demands of export interest groups. But this does not mean that the optimal political choice will always be retaliation. For instance, an injured state may decide it is expedient to avoid or postpone retaliation, especially if it believes that less aggressive mechanisms—-such as negotiation—may resolve the trade dispute.

At the response stage, the politicians in the injured state have to decide how best to induce the politicians in the scofflaw state to comply with their trade commitments. It is safe to assume that export interest groups reward politicians not only when they institute retaliation, but also when they have successfully induced the scofflaw state to comply with its obligations. Politicians in the injured state will thus have an incentive to choose the optimal mix of retaliation strategies that will best mobilize the scofflaw state's export interest groups against protectionism.

Mobilization is not costless, however. Indeed, mobilization entails prevailing over collective action problems that can be fairly severe. Interest group theory teaches that the greater the concentration of an industry, the greater the likelihood that it will organize because the largest firms will bear a significant share of the benefits. ${ }^{23}$ Thus, if retaliation targets a wide range of industries, mobilization will be difficult because of free-rider problems. Therefore, the injured state has an incentive to engage in targeted retaliation and focus on a discrete group of powerful industries that it believes will put sufficient pressure on politicians in the scofflaw state.

The EC's approach in the recent dispute over steel tariffs with the United States illustrates this retaliation strategy. Citing injury to the United States steel industry from increased steel imports, in March 2002 the United States decided to impose 30 percent tariffs on most imported flat-rolled steel products and 15 percent tariffs on rebar and

\footnotetext{
${ }^{23}$ For the discussion of the collective action difficulties faced by large and diffuse interest groups, see Mancur Olson, The Logic of Collective Action 33-43 (1965).
} 
stainless steel. ${ }^{24}$ The EC, Japan, Korea, and Brazil immediately filed a claim against the steel tariffs before the WTO arguing that they violated a variety of non-discriminatory WTO provisions. After prevailing before the WTO's appellate body, ${ }^{25}$ the EC published a retaliation list that threatened sanctions against $\$ 2.2$ billion worth of United States goods unless the United States lifted the steel tariffs by early December $2003 .{ }^{26}$ Of particular interest, however, was the political dynamics of the EC's retaliation strategy. The EC understood that the disputed steel tariffs would help shore up political support for President Bush in certain swing states like West Virginia, Pennsylvania and Ohio. In response, the EC specifically targeted a range of industries for retaliation located in states that are likely to be political battlegrounds in the 2004 presidential election such as Florida, South Carolina, Washington, and North Carolina. ${ }^{27}$ For instance, as much as 100 percent tariffs were going to be tacked unto certain goods like fruit juices, apples, dried vegetables, $\mathrm{t}$-shirts, and other products from these battleground states. ${ }^{28}$ The EC ostensibly put the President into a political dilemma: he could keep the steel tariffs and reap political spoils in Ohio and Pennsylvania, or he could face a political backlash from industries subject to retaliation in states like Florida. On the eve of the EC's retaliation deadline, President Bush decided to scrap the steel tariffs. ${ }^{29}$

The United States' approach in the European Community (EC) Bananas case is also another example of the use of a politically calibrated retaliation strategy. ${ }^{30}$ In 1999 ,

${ }^{24}$ See Presidential Proclamation No. 7529, March 5, 2002, 67 Fed. Reg. 10553 (March 7, 2002).

${ }^{25}$ See WTO Appellate Body, United States--Definitive Safeguard Measures On Imports of Certain Steel Products, WT/DS248 /AB/R (adopted Dec. 10, 2003), available at http://www.wto.org.

${ }^{26}$ Actually a provisional retaliation list was released by the EC in the summer of 2002. See Council Regulation (EC) No 1031/2002 (June 13, 2002), available on http://europa.eu.int.

${ }^{27}$ See James Cox, Sparks Fly over U.S.-E.U. Trade, USA TODAY, Nov. 11, 2003, at A3 (discussing political benefits to George Bush of steel tariffs and the political sensitivity of threatened retaliation by the $\mathrm{EC})$.

${ }^{28}$ See Council Regulation (EC) No 1031/2002 (June 13, 2002), available on http://europa.eu.int.

${ }^{29}$ See Bush Ends Steel Safeguard Tariffs in Face of Threat by EU to Retaliate, 20 Int'l Trade Rep. (BNA) 2021 (Dec. 11, 2003).

${ }^{30}$ For the panel report on the EC-Bananas dispute, see WTO Panel Report on the European Communities-Regime for the Importation, Sale and Distribution of Bananas, WT/DS27/R/USA (May 22, 1997). For the appellate body report, see WTO Report of the Appellate Body on the European Communities-Regime for the Importation, Sale and Distribution of Bananas, WT/DS27/AB/R (Sept. 9, 
the United States imposed 100 percent duties on a range of European imports worth $\$ 192$ million after the EC refused to conform its banana import regime to a WTO ruling. ${ }^{31}$ In imposing these sanctions, the United States Trade Representative (USTR) deliberately targeted a range of key products from powerful European industrial sectors and imposed tariffs that were sufficiently high to preclude those products altogether from the American market. ${ }^{32}$ The list of products affected by the tariffs were very specific and were chosen by the USTR with input from interested members of the American business community. Thus, rather than imposing lower tariffs on a much wider range of products, which would have created collective action problems, the USTR focused on a narrower (but significant) cluster of industries, which would face less obstacles in organizing and applying political pressure on the scofflaw state's politicians.

Commentary and actions by politicians and business interests on both sides of the Atlantic suggests that the United States' retaliation strategy in the EC Bananas dispute was quite effective. For instance, by early as mid-1999, Italy, which saw its lucrative handbag industry shut-out from the American market by the prohibitive tariffs, was eager to settle the dispute. ${ }^{33}$ When compliance was not forthcoming initially, the United States Congress decided to up the ante and passed legislation in May 2000 that explicitly required the USTR to rotate retaliatory tariffs every 180 days if a country continues not to comply with WTO rulings. ${ }^{34}$ Shortly afterwards, the USTR proposed new EC products

1997). For an in-depth and detailed review of the controversy underlying this famous dispute, see Raj Bhala, The Bananas War, 31 MCGEORGE L ReV 839 (2000).

${ }^{31}$ See USTR Press Release 99-17, United States takes Customs Actions on European Imports (Mar. 3, 1999), available at www.ustr.gov/releases/1999/03/99-60.pdf., (hereinafter USTR Bananas Press Release). For the DSU arbitration decision authorizing the United States to suspend concessions, see European Communities-Regime for the Importation, Sale and Distribution of Bananas European CommunitiesRecourse to Arbitration by the European Communities Under Article 22.6 of the DSU, WTO/DS27/ARB (April 9, 1999) (hereinafter EC-US Bananas Arbitration Decision). The United States picked the earlier date of March 3 to impose retaliatory measures because that was the date the arbitration panel's decision was originally due. See Daniel Pruzin, US Blocks EU Request for Banana Panel While Hormone Beef Issue Simmers at WTO, 16 Int'l Trade Rep. (BNA) 945 (June 2, 1999).

${ }^{32}$ See USTR Bananas Press Release, supra note 31.

${ }^{33}$ See James Blitz and Frances Williams, Italians Urge EU to Retreat in Banana Dispute with the U.S., Fin. Times, Jan. 27, 1990, at 6.

34 This "carousel" sanctions plan was part of the African and Caribbean Trade Act of 2000, Pub. L. No. 106-200, 114 Stat. 251 (2000), codified in various sections of 19 U.S.C. (2000). 
that would be targeted by retaliation and sought comments as to whether the then existing 100 percent tariffs were high enough to induce compliance. ${ }^{35}$ Faced with even more concentrated prohibitive sanctions, the EC capitulated and decided to settle the dispute in $2001 .^{36}$

One significant caveat: the efficacy of a well-calibrated retaliation strategy may depend on whether it addresses primarily protectionist trade restrictions. To the extent a restrictive trade measure is multifaceted and substantially affects a broader range of other politically salient interest groups, then a retaliation remedy may be less effective. For instance, the United States and Canada recently adopted a fairly calibrated retaliation strategy in a dispute involving EC restrictions on the importation of hormone-treated beef products. ${ }^{37}$ But that strategy has hardly been effective in inducing compliance by the EC. One possible explanation is that the EC ban on hormone-treated beef might not be motivated mainly by protectionist reasons but by other factors, such as EC consumer preferences regarding the health effects of such products. But this limitation in the WTO's enforcement mechanism does not necessarily prove that retaliation is an ineffective strategy; indeed, it might prove the opposite. One might argue, as many

\footnotetext{
${ }^{35}$ See WTO: USTR Steps Up Pressure on EU to Comply with Beef and Banana Rulings, 17 INT'L TRAdE Rep. (BNA) 853 (June 1, 2000).

${ }^{36}$ See U.S. Trade Representative Announces the Lifting of Sanctions on European Products as EU Opens Market to U.S. Banana Distributors (July 1, 2001), USTR Press Release, available at http://usinfo.state.gov/topical/econ/wto/pp0701.htm; USTR Press Release 01-23, Joint United StatesEuropean Union Press Release: U.S. Government and European Commissions Reach Agreement to Resolve Long-Standing Banana Dispute (Apr. 11, 2001).

${ }^{37}$ In 1999, after the EC refused to comply with a WTO ruling that its restrictions were inconsistent with the WTO's Agreement on the Application of Sanitary Phytosanitary Measures (the "SPS" Agreement), the United States sought WTO authorization to retaliate. See European CommunitiesMeasures Concerning Meat and Meat Products (Hormones)-Recourse to Arbitration by the European Communities Under Article 22.6 of the DSU, WT/DS26/ARB (July 12, 1999). After the WTO approved level of tariff suspensions worth $\$ 116.8$ million, the United States imposed 100 percent retaliatory tariffs on a specific range of EC agricultural products. USTR Announces Final Product List in Beef Hormones Dispute, USTR Press Release, July 19, 1999, available at www.ustr.gov/releases/1999/07/99-60.pdf. (hereinafter USTR Beef Hormones Press Release). Interestingly, in deciding which items to target for retaliation, the United States also factored in the political influence of the EC member states producing the item. See Rosemary A. Ford, The Beef Hormone Dispute and Carousel Sanctions: A Roundabout Way of Forcing Compliance with World Trade Organization Decisions, 27 BROOKLYN J. INT'L L 543, 568 (2002) (observing that the United States "eventually scaled back the quantity of [pork] products targeted because it did not want to unfairly burden Denmark, the EU's largest pork producer, as Denmark is a relatively small EU member state lacking large political influence.").
} 
commentators have suggested, that the WTO's enforcement mechanism should only apply to trade restrictive measures that are primarily motivated by protectionism. ${ }^{38}$ Indeed, the WTO explicitly provides that members may adopt otherwise discriminatory measures for a variety of regulatory reasons provided such measures are not disguised protectionist barriers. ${ }^{39}$

The foregoing analysis suggests that mobilizing core export interest groups through targeted retaliation is a key variable in promoting trade liberalization. Facing political pressure from domestic export groups, politicians in the injured state strategize as to how to mobilize export groups in order to exert the maximum political costs on the scofflaw state. The empirical evidence suggests that the politicians in the injured state often choose a retaliation strategy that applies prohibitively high tariffs to a discrete set of products from powerful export industries in the scofflaw state. This strategy accords with what public choice theory predicts, which is that concentrated industries that face disproportionately large costs or benefits from political decisions are better positioned to overcome collective action problems.

\section{B. Evaluating other Remedial Options}

By forcing politicians in the scofflaw state to internalize the costs of defecting from international trade commitments, retaliation has proven to be a fairly reliable enforcement strategy. Nonetheless, many commentators consider the emphasis on retaliation in international trade agreements as an obstacle to trade liberalization. ${ }^{40}$ For instance, some have argued that retaliation is a perverse enforcement device because it

\footnotetext{
${ }^{38}$ See, e.g., Eugene Kontorovich, The Arab League Boycott and WTO Accession: Can Foreign Policy Excuse Discriminatory Sanctions, 4 CHI. J. INT'L L. _ (forthcoming 2003) (discussing scholarly literature on whether GATT only prohibits discriminatory trade barriers that are imposed for protectionist reasons).

${ }^{39}$ For instance, article XX of the GATT provides that members may adopt regulatory measures to "protect human, animal or plant life or health," so long as these measures do not constitute "a disguised restriction on trade." GATT, Octo. 30, 1947, 61 Stat. A-11, T.I.A.S 1700, 55 U.N.T.S. 194.

${ }^{40}$ See, e.g., Kym Anderson, Peculiarities of Retaliation in WTO Dispute Settlement, 1 WORLD TRADE REV. 123, 128 (2002); Steve Charnovitz, Rethinking WTO Trade Sanctions, 95 AM. J. INT’L L. 792, 814-24 (2002); Jagdish Bhagwati, After Seattle: Free Trade and the WTO, 77 INT'L AfF. 15, 28 (2001); Petros Mavroidis, Remedies in the WTO Legal System: Between a Rock and a Hard Place, 11 EUR. J. INT'L L 763, (2000); Joost Pauwelyn, Enforcement and Countermeasures in the WTO: Rules are Rules-Toward a More Collective Approach, 94 Am. J. INT'L L. 335, 346 (2000).
} 
tends to hurt the injured state's economy. ${ }^{41}$ Others argue that it helps entrench protectionist interests since it implicitly provides benefits to protectionist groups in the injured state rather than the export groups that have been harmed. ${ }^{42}$ These commentators argue that other remedial options are likely to achieve better compliance.

One remedial option widely endorsed by commentators involves the payment of a monetary fine to the injured state. ${ }^{43}$ Economists like monetary fines because unlike retaliation it does not impose any costs on the injured states and it could be used directly to compensate export interest groups harmed by trade inconsistent measures. ${ }^{44}$

One obvious limitation with the imposition of monetary fines is that it is not a self-enforcing remedy. In other words, unlike retaliation, the successful imposition of monetary fines depends on some affirmative act by the scofflaw state. A scofflaw states that is adjudicated in violation of its international trade commitments may simply refuse to pay. One way to get around this problem would be to set-up bonding arrangements where each state contributes a certain amount of money to meet any contingent obligations. But even this approach will have its limitations. For instance, determining the appropriate escrow amount for each state would be unduly complex and burdensome. Moreover, states that are cash-strapped may be unwilling or unable to meet their escrow obligations. Perhaps because of these difficulties, there are very few examples of international agreements that incorporate monetary fines as a remedy.

A more significant problem with the monetary fine remedy is that such a measure is unlikely to have a disciplining effect on politicians in the scofflaw state because the burden of the fine is likely to be borne by diffuse weak groups. ${ }^{45} \mathrm{~A}$ key feature of a good

\footnotetext{
${ }^{41}$ See Anderson, supra note 40 at 128; Charnovitz, supra note 40 at 815-16; Mavroidis, supra note 40 at 774 .

${ }^{42}$ See Anderson, supra note 40 at 128.

${ }^{43}$ See Bhagwati, supra note 40 at 28; Marco Bronckers, More Power to the WTO? J. INT'L EcON. L. 41, 62 (2001).

${ }^{44}$ See Bronckers, supra note 43 at 62; Pauwelyn, supra note 40 at 346.

45 See Daryl Levinson, Making Government Pay: Markets, Politics, and the Allocation of Constitutional Costs, 67 U. CHI. L. REV. 345, 374-78 (2000) (making the point that unlike private actors, governments are not necessarily deterred by compensation requirements because politicians can effectively shift the monetary costs to inert political groups).
} 
enforcement strategy is its ability to mobilize another powerful domestic interest group against the interests of the disfavored interest group. A retaliatory strategy that focuses on the suspension of trade concessions possesses this feature, but monetary fines do not. In the case of monetary fines, it is a fairly dispersed group of taxpayers in the scofflaw state that is very likely pick up the tab. Ultimately, politicians facing mounting pressures by domestic protectionist groups to breach trade commitments are unlikely to be deterred by the prospect of having to pay fines from a general revenue fund. ${ }^{46}$

A more nuanced approach would impose the fines directly on the protectionist groups that instigated the violation of the WTO obligation. ${ }^{47}$ But there is little reason to believe that this option is practically feasible. Such an approach will very likely encounter strong resistance from protectionist groups, which are more likely to overcome collective action problems than taxpayers. In the end, prudent politicians will try to raise funds from a source where there are least likely to encounter sustained political resistance, such as a general judgment fund financed by taxpayers.

Another remedial option involves the imposition of collective sanctions on the scofflaw state. For instance, Kenneth Abbott has suggested that the WTO adopt a community sanction approach that would "authoriz[e] the suspension of concessions by however many contracting parties and in whatever amounts are thought necessary to induce compliance or to punish bad faith." ${ }^{\prime 4}$ Again, this approach is problematic because it will very likely result in the oversupply of protectionist benefits. Third-party states that are not harmed by a breach will be susceptible to incentives to choose a retaliation strategy that benefits their domestic protectionist groups rather than one that induces compliance. This is because export interests groups in a third-party state are likely to be indifferent to the outcome of the dispute since they are not affected by the breach. However, politicians in such a state are likely to view an enforcement award as an

\footnotetext{
${ }^{46}$ See Levinson, supra note 45 at 377.

${ }^{47}$ See Pauwelyn, supra note 40 at 346 ("To ensure that the sector or industry that suffers the damage caused by a WTO-inconsistent measure actually benefits from the compensation, one could, alternatively, force the losing member to pay an amount of money equivalent to the damage caused."). 1

${ }^{48}$ Kenneth Abbott, GATT as a Public Institution: The Uruguayan Round and Beyond, 18 BROOK. J. INT'L L. 31, 65 (1992).
} 
opportunity to satisfy the demands of their domestic protectionist constituencies. But there is no reason to believe that the retaliation strategy chosen by the politicians in the third party state would be the same as one chosen by a state seeking to induce compliance. Thus, a collective sanction approach would likely increase the overall level of trade-distorting policies without providing any offsetting liberalization benefits. A bilateral retaliation scheme avoids this problem because export interest groups in the injured state will likely lobby for a retaliation strategy that maximizes political pressure on the scofflaw state.

\section{Protectionist Groups As CRedibility Agents IN THE WTO's ENFORCEMENT MECHANISM}

A rational state considering defection from an international trade agreement has to consider not only the potential consequences but also the probability of retaliation. In other words, such a state will have a greater incentive to defect if it believes that retaliation is not consistent with the interests of the injured party. But since potentially all states face welfare losses when they suspend trade concessions, one might wonder why we do not see more defections in international trade agreements. This Part suggests that one reason is that protectionist groups in the injured state, who stand to benefit from retaliatory measures, act as credibility agents in the WTO's enforcement scheme. The first section assumes that each state is willing to impose deadweight losses on consumers in order to placate powerful protectionist interest groups. In such a situation, protectionist groups improve the injured state's ability to commit to retaliation in a way that export groups are not able to do. The next section concludes that given uncertainty about retaliation costs, threats to retaliate may still be credible even where states have varying levels of commitment to protectionist policies.

A. The Dynamics of Interest Groups in Generating Retaliation Credibility

States that enter into international trade agreements ordinarily expect a significant degree of compliance from each other. But such agreements usually present a cooperative dilemma because states often face domestic pressures to violate their 
international trade commitments. This feature of international trade agreements has influenced trade scholars to analyze trade cooperation as a prisoner's dilemma game, in which each state has an incentive to cheat but where cooperation is preferable to mutual defection. ${ }^{49}$ In the end, cooperation is only feasible because trade agreements are openended bargains where the relationship among the parties is like a repeated game of infinite duration. ${ }^{50}$ Since such repeated games provide parties with an opportunity to retaliate in future periods, the parties have an incentive to cooperate.

Clearly, the utility of a reciprocal strategy to enforce free trade commitments depends in large part on the belief of the parties that a threat to retaliate is credible. If state A knows that retaliation is a very costly for State B, state A's strategy would be to breach all its future trade commitments to State B. Under what conditions would retaliation be a credible option for an injured state?

The answer seems to depend on certain interest group dynamics inherent in international trade agreements. In other words, in order for retaliation to be a credible strategy for state A, politicians in that state have to be willing to sacrifice the welfare interests of their constituents for the benefit of a more well-organized interest group that favors retaliation. One obvious pro-retaliation candidate would be the export interest groups that have been injured by the violation of the trade agreement. Indeed, as demonstrated in Part II, such export groups play a critical role in mobilizing politicians to retaliate against scofflaw nations. ${ }^{51}$

Reliance on political pressure from export interest groups alone, however, would very likely result in a suboptimal retaliation strategy. To shed light on why this is the case, it would be helpful to view the interaction between a scofflaw state and an injured state in the post-judgment phase as representing a war of attrition. In a typical war of attrition

\footnotetext{
${ }^{49}$ See Alan Sykes, Constructive Unilateral Threats in International Economic Relations: The Limited Case for Section 301, 23 LAW \& POL'Y INT'L Bus. 263, $273-74$ (1992); Kenneth W. Abbott, The Trading Nation's Dilemma: The Functions of the Law of International Trade, 26 HARV. INT'L L.J. 501, 503-04 (1985).

50 See Sykes, Constructive Unilateral Threats, supra note 49 at 274 (observing that in such games of infinite durations "the players then can threaten to respond to a breach of the agreement by the other party with some sort of retaliatory breach strategy, and this threat can be forever effective as a deterrent, because the game is never expected to end soon.")

${ }^{51}$ See discussion supra text accompanying notes 23-41.
} 
model, each state tries to hold out for some benefit with the expectation that the other side will eventually concede..$^{52}$ Holding out, however, imposes significant costs on both parties. In the end, the state that first reaches its breaking point loses the game.

The depiction of the post-judgment phase of the interaction among disputing states as a war of attrition model is useful for a variety of reasons. First, the scofflaw state fits the war of attrition model because it will suffer from retaliation costs the longer it holds out against conforming to its trade obligations. If the scofflaw state is indifferent to the retaliation costs, then it has no breaking point and the injured state's strategy is irrelevant. If we assume, however, that the scofflaw state is unwilling to bear the costs of retaliation indefinitely, then it has an incentive to engage in a war of attrition against the injured state only if it believes that the injured state also has a breaking point.

Second, the injured state will fit the war of attrition model if it relies only on export group pressure because it will then also have a breaking point. To illustrate why this is so, assume that both consumers and export interest groups in an injured state are willing to invest some positive political expenditure to influence a retaliation outcome. Let the consumers' political expenditure (against retaliation) equal $c$ and the export interest groups' expenditure (for retaliation) equal $e$. In the post judgment phase, at time $t$ $=0$, it is safe to assume that $\mathrm{e}>\mathrm{c}>0$ because export groups would be better able to overcome collective action problems than consumer groups. But for these export interest groups, the level of expenditure that they are willing to invest at any specific time is a function of their beliefs regarding the probability of compliance by the scofflaw state. In other words, if the export groups believe that the scofflaw state is unlikely to comply even in the face of retaliation, they would be less willing to invest in retaliation. In turn, the export groups' belief about the scofflaw state's probability of compliance is also a function of the amount of time the scofflaw state spends not complying. We would expect that the longer the scofflaw state holds out, the greater the likelihood that it will never comply. At

\footnotetext{
${ }^{52}$ For a discussion of the war of attrition model, see DREW FUDENBERG \& JEAN TiROlE, GAME THEORY 119-26 (1991). For some applications of the war of attrition model to legal regimes, see Nicolas Marceau \& Steeve Mongrain, Damage Averaging and the Formation of Class Action Suits, 23 INT’L REV. L. \& ECON. 63 (2003); James Morrow, The Laws of War, Common Conjectures, and Legal Systems in International Politics, 31 J. LEGAL STUD. 41 (2002).
} 
time $t_{n}$, where $e=\mathrm{c}$, the political costs and benefits of retaliation to the injured state are now equal and the injured state would have reached its breaking point. In other words, at time $t_{n}$, which is when the injured state will concede the game if the scofflaw state has not already done so, the export groups' marginal happiness from retaliation is now equal to the consumers' marginal resentment. Figure 1 below is a simple graphical depiction of the injured state's breaking point when only export groups are investing political expenditures in favor of retaliation.

Level of political expenditure

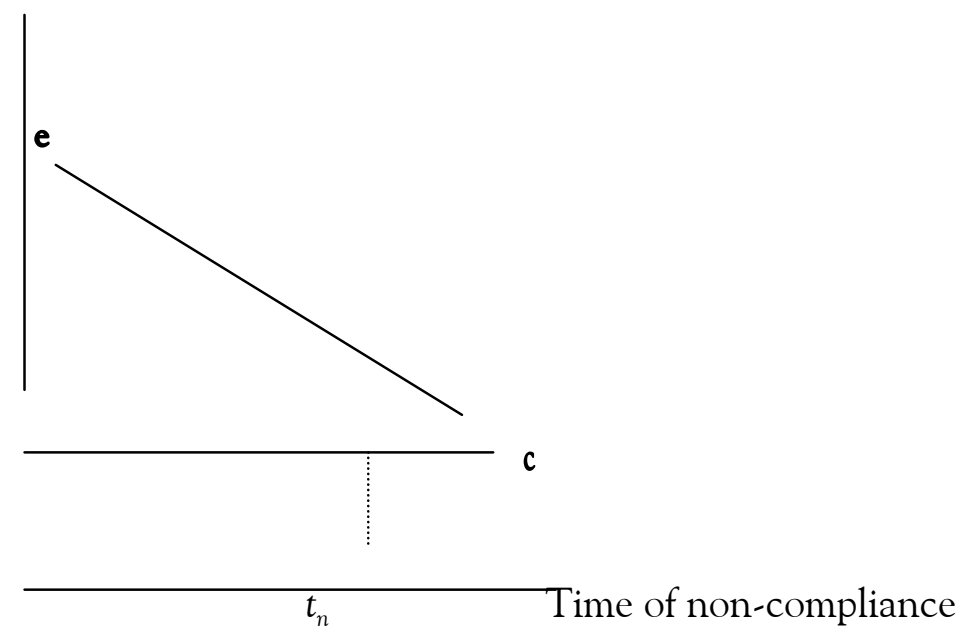

FIGURE 1: The Injured State's Breaking Point in War of Attrition

Let us change the model and assume that the injured state also has significant protectionist groups that would also benefit from retaliation. Assume further that the protectionists are willing to invest a level of political expenditure equal to $p$ to support retaliation against the scofflaw state. If we assume that the protectionist interest groups are better positioned to overcome collective action problems than consumers, then $p>c$. Moreover, since protectionists stand to benefit from retaliatory tariffs regardless of whether or not the scofflaw state complies, the level of $p$ is likely to remain constant over time. Thus, the total marginal political expenditure in favor of retaliation in the injured state $=p+e$. In this picture, the injured state no longer has a breaking point because it 
would be willing to commit to retaliation indefinitely. In other words, even though politicians in the injured state still incur political costs from holding out, such costs are offset by the political benefits they obtain from protectionist groups. Figure 2 depicts the marginal political expenditure in favor of retaliation in the injured state when significant protectionist interest groups are present.

Level of political expenditure

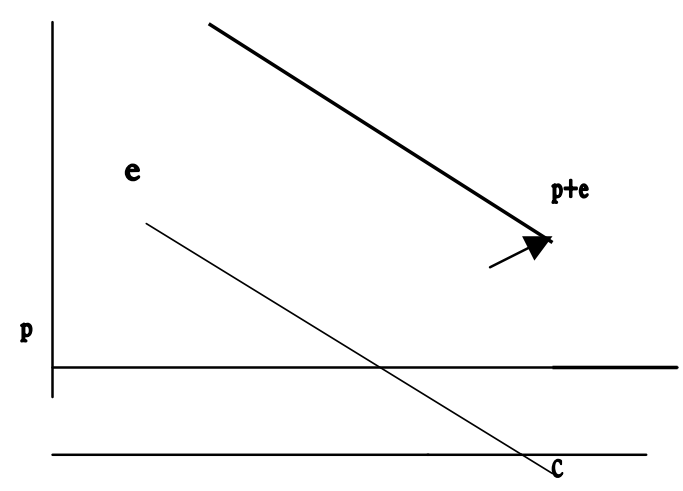

Time of non-compliance

FIGURE 2: The Injured State's Political Expenditure with Protectionist Groups

The foregoing analysis shows that a domestic political environment has significant implications for the strategic interactions among states at the enforcement phase of an international trade dispute. If a scofflaw state has a breaking point but it believes that the injured state does not have one because of significant protectionist pressures, then it has strong incentives to comply even before the injured state retaliates. In other words, the presence of a significant protectionist group in the injured state improves the injured state's ability to influence the compliance incentives of the scofflaw nation. This dynamic interaction suggests a somewhat paradoxical result: the presence of strong protectionist groups in potential injured states may be instrumental in generating credibility in the WTO's enforcement mechanism. 


\section{B. Asymmetric Retaliation Costs and the Role of Uncertainty}

The analysis in the previous section assumed a condition in which states value the interests of protectionist groups over those of consumers who are harmed by import restrictive policies. While this may represent the political reality in many major democracies, the actual commitment of political actors to protectionist policies varies across states. There are two major reasons why we might expect political actors to sometimes value the welfare interests of consumers over those of protectionist interest groups.

First, politicians in non-democratic states that do not face electoral constraints may have less of an incentive to value the interests of protectionist groups. ${ }^{53}$ Second, and more significantly, certain consumer groups in democratic states may be able to overcome collective action problems and become more politically potent than protectionist groups. This latter situation is likely to be the case consumer groups consists of industrial concerns that import many of their inputs. For instance, the unilateral repeal of agricultural tariffs by the British government in the nineteenth century has been largely attributed to the pressure of a well-organized coalition of industrial concerns that favored free trade policies. ${ }^{54}$ More recently, in various WTO disputes, industrial consumer groups in the United States and the European Community have strongly lobbied against retaliation measures that would raise the costs of their inputs. ${ }^{55}$

With complete information regarding each state's preference for protectionist policies, states might be able to foresee what would happen if they breached their free

\footnotetext{
${ }^{53}$ In such states, the significance of interest group pressure on political actors is much more ambiguous and hard to predict. For instance, Robert Putnam described a Yugoslav negotiator who, referring to the late dictator, Marshall Josip Tito, said, "the [leader] can always influence opinion if [he] wants to." Robert Putnam, Diplomacy and Domestic Politics: the logic of two-level games, 42 INT'L ORG. 427, 451 (1988).

54 See Cheryl Schonhardt-Bailey, Lessons in Lobbying for Free Trade in $19^{\text {th }}$ Century Britain: To Concentrate or Not, 85 AM. Pol. Sc. REv. 37, 43 (1991); Gary Anderson \& Robert Tollison, Ideology, Interest Groups and the Repeal of the Corn Laws, 141 J INST'L AND THEORETICAL ECON. 197 (1985).

${ }^{55}$ See Raj Bhala, The Bananas War, 31 MCGEORGE L. Rev. 839, 951 (2000) (observing that American importers during the Bananas' dispute "chafed at the uncertainty created by the [retaliation] carousel mechanism, and at the prospect of suffering heavy losses, even insolvency, as a result of retaliatory tariffs"); Geoff Winestok, How One Trade Dispute Fuels Another: U.S. Steel Tariffs May Stiffen EU Opposition to Tax Breaks, WALL ST. J., March 12, 2002, at A18 (observing that in WTO dispute over United States foreign sale company tax regime, EC consumers and importers were against any sanctions against the United States that would raise their costs).
} 
trade commitments. Significantly, since the credibility of a retaliation threat depends largely on the existence of a strong domestic constituency that favors retaliation, states that do not face such pressures would be at a strong tactical disadvantage in enforcing their trade agreements. For instance, state A might recognize that state B would be unwilling to commit to a long course of retaliation if it knows that state B lacks a comparatively strong domestic protectionist constituency. In such a framework, states with low retaliation costs would have in an incentive to breach their commitments to states with high retaliation costs.

In reality, however, such complete information about each state's preferences is highly unlikely. Indeed, the problem of uncertainty or asymmetric information in international relations has received considerable attention from political scientists over the past couple of years. ${ }^{56}$ In international economic relations, each state that participates in trade negotiations is likely to be uncertain about the true domestic interest preferences of other states. ${ }^{57}$ The presence of uncertainty provides an incentive for each state to understate its costs of retaliation by exaggerating the power of domestic protectionist interests. Thus, a state that may be relatively indifferent to protectionist policies may pretend that it faces strong protectionist pressures in order to signal its resolve to retaliate in the event of a breach. Political scientists and economists have argued that such bluffing strategies are common among states seeking a bargaining advantage in international negotiations. ${ }^{58}$

\footnotetext{
${ }^{56}$ See, e.g., Gerald Schneider \& Lars-Erik Cederman, The Change of Tide in Political Cooperation: A Limited Information Model of European Integration, 48 INT'L ORG. 633 (1994) (focusing on states' incentives to defect from European union); Keisuke Iida, When and How Do Domestic Constraints Matter? Two-Level Games with Uncertainty, 37 J CONF. RES. 403 (1993) (focusing on domestic group preferences during peacetime diplomatic negotiations); Bruce Bueno de Mesquita \& David Lalman, Domestic Opposition and Foreign War, 84 Am POL. SCI. REV. 747 (1990) (focusing on domestic resistance to war). This emphasis on asymmetric preferences in international relations has not escaped the attention of legal commentators. See, e.g., Howard F. Chang, Carrots, Sticks, and International Externalities, 17 INT’L REV. L. \& ECON. 309 (1997) (developing a model with asymmetric information where threats to harm global environment may be credible).

${ }^{57}$ See Iida, supra note 56 at 411-12.

${ }^{58}$ See Putnam, supra note 53 at 452; Chang, supra note 56 at 315; see also Sanford Grossman \& Motty Perry, Sequential Bargaining under Assymetric Information, 39 J. ECON. THEORY 120 (1986).
} 
Given the incentives that states have to misrepresent their true preferences regarding domestic restraints, it is reasonable to expect other states to attempt to unmask such tactical smokescreens. Indeed, one might expect that in democratic regimes, the ability of politicians to exploit private information regarding the influence of domestic constituencies would be limited. But there are many reasons why certainty about the true preferences of democratic states may still remain elusive.

First, politicians in a democratic state may be able to influence patterns of mobilization among interest groups through legislation or by manipulating institutional rules. ${ }^{59}$ Second, it is not just the size and concentration of interest groups that matters, but their political clout vis a vis other groups. An interest group's political clout usually depends on two factors: (1) the intensity of the interest group's pressures and; (2) the ability of politicians to withstand such pressures. But none of these two factors is likely to be observed correctly by foreign states. Indeed, it is not clear that even domestic political insiders will have the ability to measure the relative political clout of interest groups before the actual outcome of a political bargain. ${ }^{60}$ In any event, attempts by foreign states to discern the relative political clout of domestic interest groups in international negotiations have often proven to be unsuccessful. For instance, Robert Putnam describes the futility of American efforts to understand German interest groups dynamics in the

\footnotetext{
59 See e.g., Elizabeth Garrett, Harnessing Politics: The Dynamics of Offset Requirements in the Tax Legislative Process, 65 U. CHI. L. REV. 502, 504 (1998) (arguing that budget rules in "pay as you go" provision are a "mechanism to harness the interest group activity ... in order to reach substantive tax goals more easily"). For an instance of politicians manipulating institutional rules in order to mobilize interest groups, see Helen Milner, The Interaction of Domestic and International Politics: The Anglo-American Oil Negotiations and in the International Civil Aviation Negotiations, 1943-1947 in EVANS ET. AL. ED., DOUBLE Edged Diplomacy: InTeRnational Bargaining AND DOMESTiC Politics 207, 217 (1993) (suggesting that altering the status of an oil accord from an executive agreement subject to Senate ratification enlarged the power of parties opposed to the accord and subsequently doomed the accord). Indeed, political actors have an incentive to manipulate the division of foreign affairs powers in order to maximize political leverage against foreign states. This is especially relevant since courts in the United States seem reluctant to intervene in disputes regarding the constitutional allocation of foreign affairs powers. See generally Jide Nzelibe, The Uniqueness of Foreign Affairs, 89 IOWA L REV. (forthcoming 2004).

${ }^{60}$ It is worthwhile noting that one of the most pronounced criticisms of interest group theory in international relations is that it lacks a framework for measuring interest group power and thus lacks predictive value. See John Ikenberry et al., Introduction: Approaches to Explaining American Foreign Economic Policy,42 INT'L ORG. 1, 8 (1988).
} 
wake of the 1978 Bonn negotiations to deal with global reflation. ${ }^{61}$ In that episode, both the German and the Americans seemed to face great difficulties in understanding each other's domestic politics even though they were both major democracies with relatively transparent political institutions.

In the context of WTO's enforcement regime, uncertainty about a state's domestic preferences becomes a strategic tool which helps improve the credibility of retaliation threats. To understand the role of uncertainty in this picture, let us assume that a scofflaw state knows its own private costs for non-compliance, but is unaware of the retaliation costs of the other state. If the scofflaw state's costs for non-compliance are very low relative to the political benefits it receives, it may be willing to hold out indefinitely. One such scenario would be where the domestic protectionist pressures on the scofflaw nation are so great that the politicians invariably cave in to their demands. In such a case, the injured state's retaliation costs are irrelevant because no threat of any duration is likely to deter the scofflaw state.

If we assume, however, that the scofflaw state has a definable breaking point, then it would have a different non-compliance strategy. In deciding whether to breach its commitments, the potential scofflaw state has to weigh two different risks: (1) the risk that the injured state has no breaking point because of the presence of significant domestic groups that would always benefit from retaliation, and; (2) the risk that the injured state has a breaking point but might nevertheless win the war of attrition game. The problem is that the scofflaw state has no basis for determining the injured state's true retaliation costs or breaking point ex ante. For its part, the injured state always has an incentive to pretend that it derives large benefits from retaliation and that the welfare costs it incurs from high tariffs are politically insignificant. Thus, given the presence of uncertainty, a retaliation threat by a state with a weak protectionist audience may nevertheless be credible.

${ }^{61}$ See Putnam, supra note 53 at 452 . As Putnam observes, “' $[\mathrm{g}]$ overnments generally do not do too well in analyzing each other's internal politics in crises [and I would add in normal times], and indeed it is inherently difficult." Id. (quoting GlenN H. SNYDER \& PAUl Diesing, CONFLICT AMONG NATIONS: BARGAINING, DECISION MAKING, AND SYSTEM STRUCTURE IN INTERNATIONAL CRISES 522-23 (1977)). 


\section{The Special Case of Developing Countries}

One possibility is that this paper's emphasis on retaliation as an enforcement strategy is misplaced with respect to developing countries. Such countries, many commentators and diplomats argue, lack the requisite market power to utilize retaliation effectively against more powerful trading units like the United States or the EC. ${ }^{62}$ More significantly, some of these commentators argue, developing states fear that they may be subject to future sanctions in other foreign policy spheres if they retaliate against more powerful trading partners. ${ }^{63}$

At first blush, the argument that developing countries face a disadvantage in enforcing their free trade benefits seems rather straightforward. Since developing states lack market power, the argument goes, their ability to induce developed states to comply with their trade obligations through retaliation is very limited. ${ }^{64}$ But upon further examination, however, it is not obvious why developing states would necessarily be subject to higher retaliation costs than developed states. The domestic political economy incentives for states to retaliate vary considerably. The fact that one developing state (or one developed state) may have found it difficult to retaliate in one particular dispute, such as Ecuador in the EC Bananas dispute, ${ }^{65}$ tells us very little about how other developing states might react in other disputes. Other developing states could have relatively strong protectionist audiences that might otherwise make retaliation a politically desirable option. As Bhagwati and Panagariya have recently observed, poorer countries have on the average higher protectionist barriers to trade than rich countries. ${ }^{66}$ What this observation suggests is that the political economy factors that make retaliation

${ }^{62}$ See Douglas Ierley, Defining the Factors that Influence Developing Country Compliance with and Participation in the WTO Dispute Settlement System: Another Look at the Dispute over Bananas, 33 LAW \& POL'Y INT'L BUS. 615, 640 (2002).

${ }^{63} \mathrm{Id}$.

${ }^{64}$ See id.

${ }^{65}$ See infra text accompanying notes 68-71.

${ }^{66}$ Jagdish Bhagwati and Arvind Panagariya, Wanted: Jubilee 2010 Against Protectionism, Washington University Department of Economics Working Paper (International Trade Series), Working Paper 0308017, http://www.econwpa.wustl.edu , accessed Dec. 27, 2003) (discussing evidence showing that poorcountry protection is higher than rich-country protection). 
politically attractive to certain interest groups in developed states are also likely to be present in many developing states. Indeed, recent empirical data on the role of developing countries in WTO dispute settlement suggests that developing countries are not at all disadvantaged in their ability to threaten retaliation against other states. ${ }^{67}$

A more plausible explanation for the reservation many developing countries might have about retaliation is the relative lack of choice these developing states face with respect to retaliation targets. In other words, developing countries may face a narrower range of options concerning products from developed states and many of those options may not even be politically salient industries in the developed state. Moreover, if a developing country's imports from a developed county consists largely of capital inputs for industries, then it is highly unlikely that that the developing state will possess the requisite domestic political audience that will support retaliation.

The relative lack of choice of products for retaliation from developed states does not mean that developing countries are always disadvantaged in enforcing their trade commitments. Indeed, the availability of cross-retaliation as a remedy suggests that developing countries may be narrowing any enforcement gap with developed states, to the extent such an enforcement gap exists. The efficacy of cross-retaliation as an enforcement strategy was recently demonstrated by Ecuador in the EC-Bananas dispute. After the WTO ruled that the EC's regime for the importation of Bananas violated numerous GATT and GATS provisions ${ }^{68}$ Ecuador sought the right to suspend concessions against the EC ${ }^{69}$ In its retaliation request, however, Ecuador argued that since most of its imports from the EC consisted of capital goods and raw materials that were essential to its economy, it could not afford to impose any retaliatory sanctions in the goods sector. ${ }^{70}$ Instead, Ecuador requested authority under Article 22 of the DSU to cross-retaliate by

\footnotetext{
${ }^{67}$ See Marc Busch \& Eric Reinhardt, Developing Countries and GATT/WTO Dispute Settlement, Journal of World Trade (forthcoming 2003), (http://userwww.service.emory.edu/ erein/, accessed Dec. 27, 2003).

${ }^{68}$ See WTO Report of the Appellate Body on the European Communities-Regime for the Importation, Sale and Distribution of Bananas, supra note 30.

${ }^{69}$ Communication by the Permanent Mission of Ecuador, European Communities - Regime for the Importation, Sale and Distribution of Bananas, Recourse by Ecuador to Article 22.2 of the DSU, WT/DS27/52 (November 9, 1999).

${ }^{70} \mathrm{Id}$.
} 
suspending various obligations under the Agreement on Trade-Related Aspects of Intellectual Property Rights (TRIPS). In an unprecedented move, the DSU eventually granted Ecuador's request to suspend concessions worth $\$ 202$ million, with the proviso that up to $\$ 141.6$ million could be in the form of suspended intellectual property rights under the TRIPS agreement. ${ }^{71}$ In the end, the EC decided to settle its dispute with Ecuador.

Ecuador's experience with cross-retaliation illustrates one innovative response to the perceived enforcement gap between developing and developed states. Mexico has proposed another: that developing countries should have the option of auctioning off their retaliation rights to states that can benefit from them. ${ }^{72}$ The problem with Mexico's suggestion, however, is that it is prone to the same pathologies as a group sanction remedy. ${ }^{73}$ If state $\mathrm{A}$, which has been harmed by a trade inconsistent measure by state $\mathrm{B}$, auctions off its retaliation rights to state $\mathrm{C}$, then state $\mathrm{C}$ will not have much have an incentive to choose a retaliation strategy that induces compliance. Since state $\mathrm{C}$ has not itself been harmed by trade inconsistent measures, it is unlikely to be subject to a domestic political audience that wants the trade inconsistent measure removed. Instead, state $\mathrm{C}$ is more likely to choose a retaliation strategy that would maximize benefits to its domestic protectionist audience. But the problem is that a retaliation strategy that maximizes benefits for a domestic protectionist audience is not necessarily the same strategy that would induce compliance. Thus, with a regime that permits states to auction

\footnotetext{
${ }^{71}$ See European Communities - Regime For The Importation, Sale, and Distribution of Bananas Recourse to Arbitration By the European Communities Under Article 22.6 of the DSU, Arbitration Report, WT/DS27/ARB/ECU (March 24, 2000) (hereinafter EC-Ecuador Bananas Arbitration); see also Daniel Pruzin, WTO: Hailing Final WTO Decision in Banana Case Ecuador Sees Landmark For Poor Countries, Int'l Trade Daily (BNA) (March 28, 2000) (observing that the ruling "is . . the first time that the WTO has authorized "cross-retaliation" by allowing Ecuador to suspend intellectual property protection and wholesale distribution rights for EU goods and service providers.")

${ }^{72}$ See Dispute Settlement Body-Special Session-Negotiations on Improvements and Clarifications of the Dispute Settlement Understanding-Proposal by Mexico, TN/DS/W/23, (Nov. 4, 2003); See Kyle Bagwell, Petros Mavroidis \& Robert Staiger, The Case for Auctioning Countermeasures in the WTO, NBER Working Papers 9920 (http://www.nber.org/papers/w9920, accessed Dec. 27, 2003) (analyzing Mexico's auction proposal and suggesting that the auction will create both negative and positive externalities).

${ }^{73}$ See supra text accompanying note 48.
} 
off retaliation rights, one is very likely to increase the level of protectionist benefits without any offsetting incentives for increased compliance.

Finally, the related concern that developed countries may take action against developing states that exercise their retaliation rights is a red herring. ${ }^{74}$ Regardless of what enforcement mechanism that is in place, developed states may still act against developing states if the ultimate goal is to discourage developing states from vindicating their WTO rights. This concern has much more to do with the general asymmetric nature of the relationship between developed and developing states, however, than it has to do with any specific shortcomings of the retaliation remedy.

\section{SPECIFIC PERFORMANCE AND THE HAZARDS OF INFORMATION-FORCING DEVICES}

Given the centrality of uncertainty to the WTO's enforcement mechanism, the question remains: what kind of remedial goals should it have? Some economic and legal commentators have generally argued that the goal of the system is compensation and not specific performance. ${ }^{75}$ More interestingly, these commentators have argued that the WTO endorses the notion of an efficient breach, which suggests that the WTO rules do not deter the breach of an underlying trade agreement where the breach offers a pareto superior outcome. ${ }^{76}$ This Part challenges this view and argues that the injection of contractual notions of efficient breach into the WTO remedial scheme is erroneous. Section A suggests first that as a descriptive matter, contractual concepts like efficient breach or compensation do not fit well in an environment where there is no higher sovereign that can compel parties to observe their contractual obligations. The second part of the argument is more normative: given the role of uncertainty in the WTO enforcement mechanism, specific performance rather than compensation better reflects

\footnotetext{
${ }^{74}$ See Ierley, supra note 62 at 640.

${ }^{75}$ See, e.g., Warren F. Schwartz \& Alan O. Sykes, The Economic Structure of Renegotiation and Dispute Resolution in the WTO/GATT System, 31 J. Legal Stud. 179 (2002); Alan Sykes, The Remedy for Breach of Obligations Under the WTO Dispute Settlement Understanding: Damages or Specific Performance? in New Directions in International Economic Law: Essays in Honour of John H. Jackson 349 (Marco Bronckers \& Reinhard Quick eds., 2000).

${ }^{76}$ See Schwartz \& Sykes, The Economic Structure, supra note 75 at 182-85; Sykes, Specific Performance, supra note 75 at $352-54$.
} 
the trade liberalizing goals of the WTO. Section B explores the role of reciprocity in WTO regime as the strict exchange of equivalent benefits and suggests that such equivalence is grounded in customary international law norms and does not reflect an endorsement of efficient breach principles.

A. The Limitations of Efficient Breach and Other Contract Principles in the WTO's Enforcement Mechanism

Many legal and economic commentators tend to employ contractual terms like damages and efficient breach in describing the remedial goals of the WTO's enforcement mechanism. ${ }^{77}$ But trying to understand international trade agreements in such contractual terms is wrong, or is at least somewhat misleading. Agreements and disputes among states in the international realm are very much different from those in the domestic legal context. As Robert Hudec once observed, "international legal arrangements have relatively more in common with the law of primitive societies studied by anthropologists, in which litigation is still emerging as a tenuous alternative to dispute resolution by force. ${ }^{" 78}$ Hudec's observation helps explain why so many domestic contractual concepts may have little or no relevance in international law.

Take the equitable remedy of specific performance, for instance. In a domestic legal setting, the efficacy of specific performance depends on the existence of a judicial order-backed by the coercive authority of the state—that compels a promisor to perform his contractual promise. In the realm of international law, however, there is no higher sovereign that can compel scofflaw states to meet their contractual obligations. As Judith Bello notes, "the WTO has no jailhouse, no bail bondsmen, no blue helmets, no

${ }^{77}$ Schwartz \& Sykes, The Economic Structure, supra note 75 at 182-85; Sykes, Specific Performance, supra note 75 at 352-54; see also Jeffrey Dunoff \& Joel Trachtman, Economic Analysis of International Law, 24 YALE J. INT'L L. 1, 33 (1999). Perhaps these analogies thrive because some courts and commentators tend to view international treaties merely as contracts among sovereign states. See, e.g., See Trans World Airlines, Inc. v. Franklin Mint Corp., 466 U.S. 243, 253 (1984) ("A treaty is in the nature of a contract between nations."); G. Richard Shell, Trade Legalism and International Relations Theory, 44 DUKE L.J. 829, 864 (1995) (observing that "[t]he Regime Management Model of international trade dispute resolution builds on the image of trade treaties as 'contracts among sovereign states' that help stabilize cooperative trade systems.").

${ }^{78}$ Robert Hudec, Transcending the Ostensible: Some Reflections on the Nature of Litigation between Governments, 72 MINN. L. REV. 211, 212 (1987). 
truncheons or tear gas." ${ }^{79}$ Bello's observation is also true of most, if not all, international institutions responsible for implementing or monitoring international agreements. In theory, any state is almost always free to breach any of its international commitments, provided it is willing to incur the relevant reputational costs and/or face retaliation. In other words, unlike courts in domestic contract disputes, international institutions lack the mechanism to impose sanctions harsh enough that a promisor will always chose performance over non-compliance. ${ }^{80}$ This particular reality about inter-state cooperation is not a mere feature of institutional design, but is inherent in the very nature of international legal environment. For this reason, debates about whether a particular international legal regime endorses specific performance or compensation are largely misplaced. The international legal system is simply not developed enough for one to make such nuanced legal distinctions.

Given the limitations of in the international legal order, a coherent positivist analysis of the remedial goals of the WTO that employs contract analogies seems unlikely. A different, but related, inquiry could take a more normative approach: if we assume that the WTO's goals are to promote trade liberalization among its members, would specific performance or compensation better accomplish those goals?

The answer depends on the incentives generated by each remedial scheme. Generally, much of the scholarly commentary on contract remedies has focused on the award of damages or compensation. ${ }^{81}$ At the heart of the damages regime is the notion of the efficient breach, which recognizes that there are circumstances in which breaching rather than performing a contract may make one party better off, without making the (1996).

${ }^{79}$ Judith Hippler Bello, The WTO Dispute Understanding: Less is More, 90 AM. J. INT’L L. 416, 417

${ }^{80} \mathrm{Cf}$ Louis Henkin, Foreign Affairs And the United States Constitution 235 (2d ed. 1996) (observing that "[i]n principle, every nation-state has the power . . . to violate international law and obligation and suffer the consequences."). Henkin also observes that political enforcement of international law is only available in principle through the United Nations Security Council, but only for violations that threaten international peace and security. Id. at 507 n.9.

${ }^{81}$ For a collection of articles focusing on this issue, see THE ECONOMICS OF CONTRACT LAW (A. Kronman \& R. Posner eds. 1979). 
other worse off. The efficiency of this approach is seriously open to question, however, in the context of international trade agreements.

First, the efficient breach approach seems inappropriate when applied to the WTO context because it can eliminate or substantially undermine the uncertainty that is inherent in trade disputes and negotiations, rendering retaliation ineffective as an enforcement mechanism. As discussed in Part II, uncertainty about each state's retaliation costs increases the chance that retaliation will be an effective deterrent. ${ }^{82}$ This is because a scofflaw state is more likely to capitulate if it believes that there is an ex ante possibility-even if it is never brought to fruition-that it will suffer sustained noncompliance costs. However, scofflaw states that refuse to comply with the DSU recommendations in the face of retaliation can undermine this uncertainty by forcing an injured state to reveal its true retaliation costs. In the absence of uncertainty, potential scofflaw states will have an incentive to defect whenever the political costs of retaliation to the injured state are high enough to make sustained retaliation unlikely.

Ecuador's retaliation dilemma in the EC Bananas dispute underscores the significant role of uncertainty in the WTO's dispute resolution mechanism and how noncompliance undermines that role. By putting Ecuador to the test, the EC was able to demonstrate that Ecuador had significant retaliation costs, thus undermining Ecuador's ability to issue credible retaliation threats in future trade disputes within the GATT regime. In public choice parlance, Ecuador's politicians revealed a political preference for consumer interests over those of protectionist groups. In the end, however, the availability of a cross-retaliation option improved Ecuador's leverage and it showed that it was still capable of making credible retaliation threats when its WTO obligations are breached by a scofflaw state, especially when the scofflaw state has significant intellectual property interests.

Second, an efficient breach or compensatory approach is also an inappropriate fit for the WTO's enforcement scheme because retaliation does not compensate the injured party in a trade dispute. In domestic contract disputes, the efficiency rationale for the

\footnotetext{
${ }^{82}$ See supra text accompanying notes 53-61.
} 
efficient breach approach is that it provides expectation damages to the promisee while simultaneously allowing the promisor to reap any profits that exceed the losses to the promisee. ${ }^{83}$ In the international trade context, however, the remedy of retaliation does not provide any compensation or damages to the parties injured by the breach-the export interest groups in the injured state. For such export interest groups, retaliation is only a useful remedial device if it induces specific performance. Indeed, far from compensating the injured parties, retaliation actually tends to hurt the injured state, as Ecuador's experience in the EC-Bananas' dispute illustrates. And although protectionist interest groups may benefit from retaliatory actions, such benefits are clearly incidental to the goals of the WTO's enforcement mechanism. In the end, the objective of retaliation is not to compensate protectionist interest groups, but to induce compliance by scofflaw states. Indeed, various provisions of the DSU make it clear that compliance with the recommendations of the DSB is required. ${ }^{84}$ And while the DSU does provide for negotiated compensation among the disputants, it seems clear that such compensation is simply an alternative to retaliation but not to compliance. ${ }^{85}$

Recent WTO decisions and actions by WTO members support the notion that the WTO's enforcement mechanism establishes a preference for specific performance rather than compensation. For instance, arbitrators adjudicating various retaliation proposals in WTO disputes have made it clear that the objective of retaliation is to ensure

\footnotetext{
${ }^{83}$ See, e.g., Richard A. POSNER, ECONOMIC ANALYSIS OF LAW 133 (5th ed. 1998)

${ }^{84}$ See, e.g., Article 21(1) (stating that "prompt compliance with the recommendations or rulings of the DSB is essential"); Article 22(8) (observing that the DSU has an obligation to "continue to keep under surveillance the implementation of adopted recommendations and rulings, including those where compensation has been provided ..."); Id (stating that retaliation shall only be "temporary and shall only be applied until such time as the measure found to be inconsistent with a covered agreement has been removed.").

${ }^{85}$ See John Jackson, The WTO Dispute Settlement Understanding-Misunderstandings on the Nature of Legal Obligations, 91 AM. J. INT'L L. 60, 62-63 (1997) (suggesting that "the overall gist of those clauses [of the DSU] . . . strongly suggests that the legal effect of an adopted panel report is the international obligation to perform the recommendation of the panel report"); Petros C. Mavroidis, supra note 40 at 773: (“[A] WTO member should not be presumed to be in compliance with its international obligations when it continues an illegal act and at the same time wither it agrees to pay compensation or concessions in its favor are suspended"); Stefan Griller, Judicial Enforceability of WTO Law in the European Union Annotation to Case C-149/96, Portugal v. Council, 3 J. INT'L ECON. L. 441, 452 (2000) (“The aim of the DSU compensation provision is that both compensation as well as retaliation should be avoided by compliance with the obligations under the WTO agreement.").
} 
compliance by the non-conforming state. ${ }^{86}$ Indeed, these arbitrators have acknowledged that in the absence of such compliance "the enforcement mechanism of the WTO dispute settlement system could not function properly." ${ }^{\$ 7}$

More importantly, the actors in the various disputes have also acted as if specific performance was the goal of the WTO's remedial mechanism. In both the Bananas and Beef Hormones disputes, for instance, the EC did not take the position that it could breach its obligations indefinitely as long as it was willing to face sanctions. Indeed, prior to the eventual settlement of the Bananas dispute, the EC specifically agreed to bring its regime into compliance, ${ }^{88}$ and subsequently insisted that it had actually done so by making regulatory changes to it bananas import regime. ${ }^{89}$ The United States, for its part, argued that retaliation in the Bananas dispute was only a last resort measure designed to induce compliance by the EC. ${ }^{90}$ Indeed, the United States was so incensed by the EC's non-compliance and delay tactics in that dispute that it also considered the unusual remedy of suspending the landing rights of European airlines. ${ }^{91}$ This is hardly the kind of remedial option a party would consider in the context of a compensatory regime. In the Beef Hormones dispute, the EC's position has been that the WTO's ruling allows it to keep its ban in place until it can justify it using better scientific methods, albeit with the understanding that such a justification has to occur within a reasonable period of time. ${ }^{92}$ The United States disagrees, of course, with the EC's interpretation of the WTO's Beef Hormones decision, but none of the parties has argued that a violation of a WTO

\footnotetext{
${ }^{86}$ See EC-US Bananas Arbitration Decision, supra note 31, para. 6.3 ("We agree with the United Sates that this temporary nature [of retaliatory measures] indicates that the purpose of countermeasures is to induce compliance"); Brazil—Export Financing Programme for Aircraft, Recourse to Arbitration by Canada to Article 22.6 of the DSU and Article 4.11 of the SCM Agreement, WT/DS46/ARB (Aug. 28, 2000) (" $[W]$ e note that countermeasures are meant to induce [the State which has committed an internationally wrongful act] to comply with its obligations.”) (hereinafter Brazil-Canada Arbitration Decision).

${ }^{87}$ EC-Ecuador Bananas Arbitration Decision, supra note 31, para. 76.

${ }^{88}$ See Frances Williams, EU Accepts Ruling on Banana Regime, Fin. Times, Sept. 26, 1997, at 5.

${ }^{89}$ See Timothy M. Reif \& Marjorie Florestal, Revenge of the Push- Me, Pull-You: The Implementation Process Under the WTO Dispute Settlement Understanding, 32 INT'L LAW. 755, 778 (1998).

${ }^{90}$ See Frances Williams, EU 'Needs 8 Months' to End Banana Crisis, Fin. Times, April 20, 1999, at 9.

${ }^{91}$ See Bhala, Banana Wars, supra note 30 at 941.

${ }^{92}$ See Reif \& Florestal, supra note 89 at 782
} 
obligation is permissible provided the injured party can retaliate by suspending market concessions. ${ }^{93}$

An argument that has been raised against specific performance in international trade agreements involves the reality that trade agreements are, by their very nature, incomplete contracts. ${ }^{94}$ In other words, because trade negotiators cannot foresee all future contingencies that might constitute violations of a WTO rule, states will often face circumstances ex post that they did not anticipate would be addressed by the agreement. ${ }^{95}$ For instance, a state might find itself later in a position where it would face enormous domestic political costs if it does not violate its treaty commitments, but it might have been very difficult to anticipate that situation ex ante. In such circumstances, the proponents of efficient breach argue, states should feel free to violate their WTO commitments when compliance would otherwise be "politically infeasible," 96 provided that compensation or retaliation is available to the state[s] injured by the breach. Because specific performance would force states to comply even when the political costs of compliance are extraordinarily high, the argument goes, a compensation approach is preferable.

The argument that the GATT and the other WTO trade agreements are incomplete contracts seems somewhat indisputable. Indeed, uncertainty about future contingencies is likely to be a feature of any international agreement where states face a cooperative dilemma. It is not at all clear, however, that the enforcement of reciprocal trade obligations is best served by encouraging an efficient breach approach. Indeed, the flip side of specific performance-states tenaciously violating their trade commitments whenever they are willing to bear the retaliation costs-would very likely result in trade wars and would undermine the credibility of the WTO's enforcement mechanism. In the Bananas dispute, for instance, several United States legislators voiced strong frustration

\footnotetext{
${ }^{93} \mathrm{Id}$.

${ }^{94}$ See Sykes \& Schwartz, The Economic Structure, supra note 75 at 185.

${ }^{95}$ See id.

${ }^{96}$ Id. at 191.
} 
with the WTO dispute resolution process in the face of the EC's non-compliance with the WTO ruling in that case. ${ }^{97}$

There are two more effective ways of dealing with the problem of incompleteness in international agreements: the first is to allow the parties to renegotiate their trade commitments under various provisions of the GATT; ${ }^{98}$ the other is to encourage state parties to exercise restraint and avoid bringing "politically loaded" or sensitive cases before the WTO's dispute resolution mechanism. ${ }^{99}$ Interestingly, states seem to have adopted both of these approaches to deal with the uncertainty of domestic political pressures in trade disputes. For instance, Garrett and Smith have observed that with respect to renegotiation, the United States and the EC agreed in the 1994 Uruguay round to exclude agricultural subsidies from legal challenge until December 2003, with the understanding that further negotiations on agricultural subsidies would continue once the agreement expires. ${ }^{100}$ Admittedly, not all politically loaded trade disputes may be amenable to renegotiation, ${ }^{101}$ but states also have the option using diplomatic outlets rather than burdening the WTO with politically intractable disputes. Indeed, in 1998, the WTO's Director-General advised states to try to resolve more disputes through diplomatic channels and warned that asking the WTO to handle politically sensitive

\footnotetext{
${ }^{97}$ See Paul Blustein, U.S., EU Reach Pact on Bananas, WASH. Post, April 12, 2001, at E1.

${ }^{98}$ Article XXVIII of the GATT explicitly provides for renegotiation by allowing nations that seek to withdraw concessions to so provided that they negotiate compensatory concessions to other affected states if possible, but if not, the affected states are allowed to suspend an equivalent amount of concessions. See GATT, supra note 1, art. XXVIII. Article XIX of the GATT also authorizes states to adopt temporary measures that would otherwise be GATT-inconsistent in order to protect distressed import-competing industries. See id. at art. XIX. Yet another form of "renegotiation" may take place when states reach a tentative agreement on certain issues but agree to revisit such issues in the future. See Joel Trachtman, The Domain of WRO Dispute Resolution, 40 HARV. INT'L L.J. 333, 351 (1999) (observing that incompleteness of treaty specifications may be the result of a political decision "to agree to disagree for the moment in order to avoid the political price that may arise from immediate hard decisions.").

99 Because of the political sensitivity of many "trade and" issues, such as those that implicate environmental and security issues, some commentators have argued that the WTO should invoke use judicial avoidance techniques like the political question doctrine when asked to address such issues. See, e.g., Jeffrey L. Dunoff, The Death of the Trade Regime, 10 EuR. J. INT'L L. 733, 754-61 (1999).

${ }^{100}$ See Geoffrey Garrett and James McCall Smith, The Politics of WTO Dispute Settlement, UCLA International Institute, Occasional Paper Series, (July 31, 2002), at 13.

101 See Sykes \& Schwartz, The Economic Structure, supra note 75 at 192 (arguing that tariff renegotiations would not address the EC's concerns in the Beef-Hormones dispute).
} 
issues that were "not central to its work" would not only be "a recipe for failure[,] [i]t could do untold harm to the trading system itself." 102

The adjudication avoidance strategy seems to be the approach taken by the EC in its challenge to the United States Helms-Burton law, which penalizes certain foreign companies doing business in Cuba. Facing a credible threat by the United States that it would boycott the proceedings and refuse to comply with any WTO recommendations should it lose, the EC decided to settle the dispute with the United States. In its submission to the WTO, the United States invoked the political question doctrine in arguing that the WTO lacked competence to adjudicate on the legality of the HelmsBurton law. ${ }^{103}$ After the WTO rejected those arguments, the United States openly threatened to boycott the proceedings. ${ }^{104}$ Indeed, the threat was credible enough that trade experts voiced concern that the legitimacy of the WTO would be undermined if the dispute were to proceed to the decision phase. ${ }^{105}$

The United States' stance in the dispute over the Helms-Burton legislation seems inconsistent with the notion that the WTO embraces an efficient breach approach. If efficient breach were an option available to disputants, then one would expect United States to proceed with the case with the understanding that if it lost it could simply compensate the EC or face retaliatory sanctions. Moreover, the EC's willingness to back out of the lawsuit, rather than risk the credibility of the WTO, suggests the superiority of adjudication avoidance to an efficient breach approach. In any event, Garret and Smith have documented numerous other instances where state parties have chosen to avoid bringing cases to the WTO where domestic political pressures would make compliance with WTO recommendations difficult. ${ }^{106}$

${ }^{102}$ WTO Cannot be "Judge, Jury, Police" of Environment Issues, Top Official Says, BNA International Environmental Daily, 18 March 1998.

${ }^{103}$ Anne Swardson, U.S. Comes Out Ahead in Trade Skirmishes, SeAtTle TimES, Oct. 16, 1996, at A3.

${ }^{104}$ See Paul Blusten \& Anne Swardson, U.S. Vows to Boycott WTO Panel, WAshington Post, Feb. 21, 1997 , at A1.

${ }^{105} \mathrm{Id}$.

${ }^{106}$ See Garrett \& Smith, supra note 100 at 14 (including as examples, disputes over aircraft subsidies, and the lack of an appeal in the dispute over United States section 301 legislation). 
B. The Role of Equivalence in the WTO's Retaliation Scheme

The WTO's enforcement mechanism provides that retaliatory measures shall be "equivalent to the level of nullification or impairment."107 Various commentators have seized upon this language to argue that the DSU endorses an efficient breach approach. ${ }^{108}$ If the member states of the WTO had preferred specific performance, the argument goes, they would have provided for sanctions that were more severe than "equivalent" retaliatory measures. ${ }^{109}$ One problem with this argument is that under the domestic contract analogy, increasing the level of damages beyond that provided by expectation damages regime would simply result in a liquidated damages scheme. By definition, however, liquidated damages is not specific performance. Indeed, courts have routinely held that liquidated damages provisions that are designed to compel performance are non-enforceable. ${ }^{110}$

A more significant problem with this argument is that it overlooks the reality that the concepts of reciprocity and equivalence are pervasive throughout international law, and are not just features of the GATT/WTO framework. More importantly, the prevalence of these concepts in international law appear to reflect the reality of the asymmetries of power in international relations and the need to control the escalation of conflict in international disputes, rather than any endorsement of a notion of efficient breach.

The notions of reciprocity and equivalence in international law are not of recent vintage. As early as 1948, a commentator had proclaimed the notion of reciprocity as one of the basic principles of international law. ${ }^{11}$ More recently, Elizabeth Zoller has argued that reciprocity "is a condition theoretically attached to every legal norm of international

${ }^{107}$ See Article 22.4 of the DSU.

${ }^{108}$ See Sykes, Specific Performance, supra note 75; Sykes \& Schwartz, The Economic Structure, supra note 75 at $182-85$.

${ }^{109}$ David J. Bederman, Counterintuiting Countermeasures, 96 AM. J. INT’L L 817, 818 (2002)

110 See e.g., Brecher v. Laikin, 430 F. Supp. 103, 106 (1977); but see Thomas Ulen, The Efficiency of Specific Performance: Toward a Unified Theory of Contract Remedies, 83 Mich. L. REV. 341, 350-53 (arguing that courts should routinely enforce punitive liquidated damages clauses).

${ }^{111}$ Ernst Schneeberger, Reciprocity as a Maxim of International Law, 37 GEO. L. J. 34, 38 (1948). 
law." 112 Thus, we find instances of reciprocity operating in situations as diverse as the Soviet-American détente of the 1970s, ${ }^{113}$ international disputes over airline routes, ${ }^{114}$ the legality of the diversion of an international water-way, ${ }^{115}$ and the legality of the United States' military intervention in Vietnam. ${ }^{116}$ In 2001, the International Law Commission (ILC) formally adopted the concept of reciprocity or countermeasures as part of its articles on the implementation on state responsibility. ${ }^{117}$ More recently, WTO arbitrators have explicitly adopted the ILC approach in determining the appropriate level of retaliation necessary to induce compliance by the scofflaw state. ${ }^{118}$ Even though reciprocity and equivalence apply to myriad other situations in international law, no one would suggest that it reflects international law's preference for an efficient breach approach, especially as applied to armed conflict situations. ${ }^{119}$

The pervasive role of reciprocity in international law is not so difficult to understand. The lack of a centralized enforcement mechanism in the international community of states means that states often have to rely on self-help measures to achieve compliance. Anthropologists have also shown that reciprocity or a tit-for-tat approach is also very common in primitive social orders that lack formal enforcement and dispute

${ }^{112}$ Elisabeth Zoller, Unilateral Peacetime Remedies: An ANalysis of Countermeasures 15 (1984).

${ }^{113}$ See Robert Keohane, Reciprocity in International Relations, 40 INT'L ORg. 1, 2-3 (1986).

114 See Air Services Agreement of 27 March 1946 (U.S. v. Fr.), 18 R.I.A.A. 417 (1978); see also discussion in Lori Fisler Damrosch, Retaliation or Arbitration-Or Both? The 1978 United States-France Aviation Dispute, 74 Am. J. Int'l L. 785 (1980).

${ }^{115}$ See Gabcikovo-Nagymaros Project (Hung. v. Slovk.), 1997 ICJ Rep. 7 (Sept. 1975).

${ }^{116}$ Indeed, the State Department submitted a brief on the legality of the United States' intervention in Vietnam which insisted that under international law a material breach of a treaty "entitles the other at least to withhold compliance with an equivalent, corresponding, or related provision until the other party is prepared to honor its obligations, " quoted in Zoller, supra note 112 at 15 n.40.

${ }^{117}$ See Bederman, supra note 109 at 819.

${ }^{118}$ See Brazil-Canada Arbitration Decision, supra note 86, at para 3.44.

119 One notable exception to the application of retaliation, however, involves obligations affecting human rights or "other obligations affecting peremptory norms of general international law." Bederman, supra note 109 at 827; see also Zoller, supra note 112 at 26. In other words, retaliation does not apply to those obligations that states owe to each other regardless of the other party's performance. Such erga omnes obligations of states encompass practices as varied as the prohibitions against slavery, racial discrimination, genocide, and torture. See Zoller, supra note 112 at 26. 
resolution mechanisms. ${ }^{120}$ As Robert Axelrod has argued, in such environments characterized by the absence of hierarchy, tit-for-tat or reciprocity is the best strategy for inducing cooperation among egotistical actors. ${ }^{121}$ Reciprocity's success as a cooperative strategy in non-zero sum games may have a lot to do with both its "clarity" and the fact that is collectively stable across time. ${ }^{122}$ In other words, a reciprocal strategy makes each party aware in advance of the possible consequences of defection.

The notion that negative reciprocity should involve equivalent or commensurate suspension of obligations is also not surprising. Since negative reciprocity or retaliation involves exchanging "wrong for wrong," there was always the implicit risk that the strategy could escalate into a feud in which all parties could be made worse off. ${ }^{123}$ In addition, there was also the concern that any "self help" remedial scheme would likely be subject to abuse by powerful states. ${ }^{124}$ In any event, almost all reciprocity measures in international law require that a retaliatory action be roughly equivalent to the amount of the injury inflicted. ${ }^{125}$ Indeed, precisely because of the conflict escalating risk associated with negative reciprocity, Axelrod suggested that a better enforcement strategy would be to return "nine-tenths of a tit for a tat." ${ }^{126}$ In this framework, however, the utility of the strategy is not that it any way compensates the injured party, but that it provides sufficient incentives to each party "not to try gratuitous defections." ${ }^{127}$ Most recently, a WTO arbitration panel reaffirmed that the goal of an "equivalent withdrawal of

${ }^{120}$ See Zoller, supra note 112 at 14 (observing that "in primitive societies, reciprocity as the central principle of life").

${ }^{121}$ ROBERT AXELROD, THE EVOlution OF COOPERATION 136-39 (1984).

${ }^{122}$ See id. at $118-19,122-23$.

${ }^{123}$ See id. at 138.

${ }^{124}$ See Oscar Schachter, Dispute Settlement and Countermeasures in the International Law, 88 AM. J. INT’L L. 471, 472 (1994).

125 See Zoller, supra note 112 at 22 ("The limits of reciprocity are the limits of equivalence"); Keohane, supra note 113 at 8 ("Despite the impossibility of determining exact equivalence, some degree of equivalence is integral to the meaning of reciprocity").

${ }^{126}$ Axelrod, supra note 121 at 138.

${ }^{127}$ Id.; see also Brazil-Canada Arbitration Decision, supra note 86, at para. 3.44 ("We conclude that a countermeasure is 'appropriate' inter alia if it effectively induces compliance."). 
concessions" is to provide sufficient incentives to induce the scofflaw state to abandon its illegal actions, and not to compensate the injured party for its damages. ${ }^{128}$

In addition to conflict escalation concerns, there is another good reason why equivalent retaliation in international trade disputes is a desirable enforcement strategy: it is fair and equitable given the existence of asymmetric trading volumes among WTO members. Any enforcement strategy that gives states the power to retaliate by suspending more than equivalent trade concessions would impose an unfair burden on states with low volumes of trade concessions. To illustrate, let us assume that both states $\mathrm{B}$ and $\mathrm{C}$ have suffered an equivalent amount of harm from state A's refusal to comply with its trade commitments, let us say $\$ 20$ million. Let us also assume that the total amount of state trade concessions that state B has offered to state A is $\$ 140$ million and state C's total amount of trade concessions to state $\mathrm{A}$ is $\$ 30$ million. Finally, let us assume further that both states $\mathrm{C}$ and $\mathrm{B}$ have been granted the authority to retaliate against state $\mathrm{A}$ by suspending trade concessions equal to two times the amount of injury they have each suffered, that is $\$ 40$ million. In this picture, state $\mathrm{C}$ is at a disadvantage because it can only suspend up to $\$ 30$ million worth of trade concessions whereas state $B$, which suffered the same level of injury as state $\mathrm{C}$, can easily afford to suspend trade concessions of up to $\$ 40$ million. Thus, if we had a trade enforcement regime that allowed "more than a tit for a tat," it would necessarily be unfair to states that do not have a significant volume of trade concessions.

\section{CONCLUSION}

Using the tools of public choice analysis, this Article examines the interaction of domestic interest groups and the WTO retaliation mechanism and argues that this interaction provides significant benefits that are lacking in alternative remedial schemes. First, by penalizing powerful export interest groups in a scofflaw state, retaliation enables

${ }^{128}$ See Brazil-Canada Arbitration Decision, supra note 86, at para. 3.54 ("[I]f the actual level of nullification or impairment is substantially lower than the subsidy, a countermeasure based on the level of nullification or impairment will have less or no inducement effect and the subsidizing country may not withdraw the measure at issue."). 
political actors in scofflaw states to internalize the costs of defection from their free trade commitments. Second, the presence of protectionist interest groups in the injured state (or more correctly, the perception of the presence of such groups) may powerfully influence the injured state's ability to make credible threats to retaliate. This Article also suggests that uncertainty about each state's retaliation costs makes retaliation a credible enforcement strategy even when states have varying levels of commitment to protectionist policies.

Finally, this Article contends that the significant role of uncertainty in this model suggests that specific performance, and not compensation, should be the goal of the WTO's enforcement mechanism. As a descriptive matter, attempts to interject contractual notions of compensation and efficient breach into the WTO's enforcement mechanism are wrong or misleading. This is because the legal system that characterizes the international trade regime is too rudimentary to admit of such domestic contract analogies. More importantly, as a normative matter, this Article concludes that the WTO's goals of market liberalization would be better attained through a specific performance approach: first, specific performance preserves the uncertainty that is integral to the functioning of the WTO's enforcement mechanism; second, specific performance is the only remedy that is actually of use to the export groups in the injured states— the parties actually injured by a scofflaw state's breach of its obligations.

Readers with comments may address them to:

Jide Nzelibe University of Chicago Law School

1111 East 60th Street

Chicago, IL 60637

jnzelibe@law.uchicago.edu 


\section{University of Chicago Law School}

\section{Public Law and Legal Theory Working Paper Series}

1. Cass R. Sunstein and Edna Ullmann-Margalit, Second-Order Decisions (November 1999; Ethics, v. 110, no. 1).

2. Joseph Isenbergh, Impeachment and Presidential Immunity from Judicial Process (November 1999; forthcoming Yale Law and Policy Review v.18 \#1).

3. Cass R. Sunstein, Is the Clean Air Act Unconstitutional? (August 1999; Michigan Law Review \#3).

4. Elizabeth Garrett, The Law and Economics of "Informed Voter" Ballot Notations (November 1999, University of Virginia Law Review, v. 85).

5. David A. Strauss, Do Constitutional Amendments Matter? (November 1999)

6. Cass R. Sunstein, Standing for Animals (November 1999)

7. Cass R. Sunstein, Culture and Government Money: A Guide for the Perplexed (April 2000).

8. Emily Buss, Without Peers? The Blind Spot in the Debate over How to Allocate Educational Control between Parent and State (April 2000).

9. David A. Strauss, Common Law, Common Ground, and Jefferson's Principle (June 2000).

10. Curtis A. Bradley and Jack L. Goldsmith, Treaties, Human Rights, and Conditional Consent (May 2000; Pennsylvania Law Review v. 149).

11. Mary Ann Case, Lessons for the Future of Affirmative Action from the Past of the Religion Clauses? (May 2001, Supreme Court Review, 2000)

12. Cass R. Sunstein, Social and Economic Rights? Lessons from South Africa (May, 2000).

13. Jill Elaine Hasday, Parenthood Divided: A Legal History of the Bifurcated Law of Parental Relations

14. Elizabeth Garrett, Institutional Lessons from the 2000 Presidential Election (May 2001).

15. Richard A. Epstein, The Allocation of the Commons: Parking and Stopping on the Commons (August 2001).

16. Jack Goldsmith, The Internet and the Legitimacy of Remote Cross-Border Searches (October 2001).

17. Adrian Vermeule, Does Commerce Clause Review Have Perverse Effects? (October 2001).

18. Cass R. Sunstein, Of Artificial Intelligence and Legal Reasoning (November 2001).

19. Elizabeth Garrett, The Future of Campaign Finance Reform Laws in the Courts and in Congress, The William J. Brennan Lecture in Constitutional Law (December 2001).

20. Julie Roin, Taxation without Coordination (March 2002).

21. Geoffrey R. Stone, Above the Law: Research Methods, Ethics, and the Law of Privilege (March 2002; forthcoming J. Sociological Methodology 2002).

22. Cass R. Sunstein, Is There a Constitutional Right to Clone? (March 2002). 
23. Emily Buss, Parental Rights (May 2002, forthcoming Virginia Law Review).

24. David A. Strauss, Must Like Cases Be Treated Alike? (May 2002).

25. David A. Strauss, The Common Law Genius of the Warren Court (May 2002).

26. Jack Goldsmith and Ryan Goodman, U.S. Civil Litigation and International Terrorism (June 2002).

27. Jack Goldsmith and Cass R. Sunstein, Military Tribunals and Legal Culture: What a Difference Sixty Years Makes (June 2002).

28. Cass R. Sunstein and Adrian Vermeule, Interpretation and Institutions (July 2002).

29. Elizabeth Garrett, Is the Party Over? The Court and the Political Process (August 2002).

30. Cass R. Sunstein, The Rights of Animals: A Very Short Primer (August 2002).

31. Joseph Isenbergh, Activists Vote Twice (November 2002).

32. Julie Roin, Truth in Government: Beyond the Tax Expenditure Budget (November 2002).

33. Cass R. Sunstein, Hazardous Heuristics (November 2002).

34. Cass R. Sunstein, Conformity and Dissent (November 2002).

35. Jill Elaine Hasday, The Principle and Practice of Women's "Full Citizenship": A Case Study of Sex-Segregated Public Education (December 2002).

36. Cass R. Sunstein, Why Does the American Constitution Lack Social and Economic Guarantees? (January 2003).

37. Adrian Vermeule, Mead in the Trenches (January 2003).

38. Cass R. Sunstein, Beyond the Precautionary Principle (January 2003).

39. Adrian Vermeule, The Constitutional Law of Congressional Procedure (February 2003).

40. Eric A. Posner and Adrian Vermeule, Transitional Justice as Ordinary Justice (March 2003).

41. Emily Buss, Children's Associational Rights? Why Less Is More (March 2003)

42. Emily Buss, The Speech Enhancing Effect of Internet Regulation (March 2003)

43. Cass R. Sunstein and Richard H. Thaler, Libertarian Paternalism Is Not an Oxymoron (May 2003)

44. Elizabeth Garrett, Legislating Chevron (April 2003)

45. Eric A. Posner, Transfer Regulations and Cost-Effectiveness Analysis (April 2003)

46. Mary Ann Case, Developing a Taste for Not Being Discriminated Against (May 2003)

47. Saul Levmore and Kyle Logue, Insuring against Terrorism - and Crime (June 2003)

48. Eric Posner and Adrian Vermeule, Accommodating Emergencies (September 2003)

49. Adrian Vermeule, The Judiciary Is a They, Not an It: Two Fallacies of Interpretive Theory (September 2003)

50. Cass R. Sunstein, Ideological Voting on Federal Courts of Appeals: A Preliminary Investigation (September 2003)

51. Bernard E. Harcourt, Rethinking Racial Profiling: A Critique of the Economics, Civil Liberties, and Constitutional Literature, and of Criminal Profiling More Generally (November 2003) 
52. Jenia Iontcheva, Nationalizing International Criminal Law: The International Criminal Court As a Roving Mixed Court (January 2004)

53. Lior Jacob Strahilevitz, The Right to Destroy (January 2004)

54. Adrian Vermeule, Submajority Rules (in Legislatures and Elsewhere) (January 2004)

55. Jide Nzelibe, The Credibility Imperative: The Political Dynamics of Retaliation in the World Trade Organization's Dispute Resolution Mechanism (January 2004) 